\title{
Powder Diffraction Program Information 1990 Program List*
}

\author{
Prepared by Deane K. Smith \\ Department of Geosciences and Materials Research Laboratory, Pennsylvania State University, \\ University Park, PA 16802, USA \\ AND SYB GORTER \\ Gorlaeus Laboratories, Department of Chemistry, University of Leiden, Einsteinweg 5, NL-2333 CC Leiden, \\ The Netherlands
}

(Received 12 March 1991; accepted 15 March 1991)

Report to the IUCr Commission on Powder Diffraction.

\section{Commission Members:}

Professor R. A. Young, United States, Chairman

Dr R. J. Hill, Australia, Secretary

Professor Z. Bojarski, Poland

Dr D. E. Cox, United States

Dr J. Fiala, Czechoslovakia

Dr A. Hewat, France

Dr J. I. Langford, Great Britain

Dr D. Louër, France

Professor P.-E. Werner, Sweden

Dr T. Yamanaka, Japan

Dr L. K. Frevel, United States, ICDD Representative

Professor D. K. Smith, United States, Consultant

\section{General comments and disclaimer}

Over 280 programs for the analysis of powder diffraction data have been identified in this compilation. On the basis of information supplied by the program authors, the programs have been grouped into categories appropriate to the major type of calculation performed. The 21 categories which have been identified are:

Crystallographic databases

Analysis packages

Instrument control and data processing

$d$ generation

Graphical $d-I$ display

Phase identification

Automatic indexing

Refinement/indexing

Refinement/error analysis

* A limited number of reprints of this article are available from The Executive Secretary. International Union of Crystallography. 5 Abbey Square, Chester $\mathrm{CH} 12 \mathrm{HU}$, England.

$0021-8898 / 91 / 040369-34 \$ 03.00$
Metric analysis

Pattern generation

Profile fitting - decomposition

Profile fitting - full pattern

Deconvolution

Crystallinity/strain/texture

Rietveld - structure refinement

Quantitative analysis

Structure determination (powder)

Structure display

Small-angle scattering

Miscellaneous programs.

For each program listed, information on the programming language, type of computer needed, conditions on the availability and support of the code and the program author or alternative source for the program is provided. Addresses of program authors and references are also given for all programs where available. Compiling this information has been a considerable undertaking and many programs may have been missed. As corrections and more programs are brought to the attention of the publication authors, they will be added to the master files and an update to this list will be prepared when the time is appropriate.

Many of the programs produce the same results as do other programs in the same category, so the diffractionist certainly does not need to acquire every program in the list to have a complete system of programs. However, because there are differences in programs for similar purposes, it is usually advisable to have more than one routine from a given group. Multiple programs are particularly valuable when the calculations involve different strategies on experimental data that are not free of errors. Selection of programs for one's own use depends on the types of experiments commonly performed and on the type of computer that is available.

The questionnaire which was used to collect the program information had several questions designed

(C) 1991 International Union of Crystallography 
to obtain some statistical information on the computers in use and to determine if there might be a way to improve program distribution. There is no doubt that Fortran is still the most common programming language in use. Fortran 77 was mentioned frequently, but other Fortran compilers were also indicated. Different compilers often have some subtle differences due to extensions above the Fortran 77 standard which may mean that the codes may not compile the first time on a different compiler. The diagnostics produced usually flag the problems sufficiently for the typical programmer to work around the problem. Maybe $10 \%$ of the cases will involve more elaborate corrective measures.

Basic was the other language used frequently, mostly for PC programs. The problems of porting programs from one level of Basic to another is similar to Fortran, but the differences are greater. Many of the main-frame computers have Basic compilers which can intepret the PC languages, but it is usually easier to go from the main-frame to the PC than vice versa. Other languages such as $\mathrm{C}$ and Pascal were used in very few cases. It is evident that a universal language would be ideal, but it will never be developed.

The most common main-frame computers mentioned are the IBM and VAX series, but FACOM, Cray and others are used. Among the PC types, the IBM and compatibles were the most common, but the diversity of other manufacturers was significant. There was more variety in Europe and Japan than elsewhere. The Macintosh, which is a common system in the US for offices and manuscript preparation, was barely mentioned. The diversity of computers complicates the portability of programs, particularly when file manipulations are involved. Regardless, there has been considerable success in porting programs from one computer to another.

Program documentation also shows diversity both in the manner presented, some as text files and others as manuals, and in the detail that is in the instructions. Programs which are distributed free usually have very skimpy instructions. Some expensive commercial programs are well documented but not all. Preparing good manuals is difficult and time consuming. Freeware usually does not justify the necessary time as there are few benefits to the program author. For commercial programs, there is no excuse for poor instructions. For ease of distribution, the machine-readable file is ideal, but a good manual is easier to use and easier to illustrate with equations, plots and sketches. Examples of worked problems should always be provided to assist the user in implementing programs for the first time and as tests that the program has been installed properly.

A general problem the publication authors have found with most of the programs that have been tried is the difficulty of setting up the input files. Very few of the routines have an interactive frontend set-up program and those that do rarely test the interactive responses for reasonableness. Default values or reasonable responses should be offered for every question and any answer entered should be tested by the program and rejected if it falls outside a preset range. The rejection should return the respondent to the question rather than corrupt file preparation or accept the bad value for later disruption of the run. For example, if a wavelength of $200 \AA$ is entered, it should not be accepted. Hopefully, future versions of popular programs will improve in this aspect.

One of the questionnaire inquiries was designed to test the interest and to evaluate the feasibility of establishing some means for assisting with program distribution. One option would be to set up a few centres willing to maintain the most current versions of programs supplied by program authors and to provide program copies on request for a copying charge. The advantage of the centre would be the currentness but the disadvantage would be the time and effort required to maintain the operation. In fact, the Dutch Association of Crystallographers have already founded such a centre.

The other problem with a central distribution centre is only a partial acceptance of the idea by the program authors. Many program authors would welcome the chance to supply only one centre with current versions but other program authors prefer to maintain more control over the program distribution. Commercial programs would have to be distributed by the producer. Obviously, full implementation of this option is not imminent.

The publication authors make no claim with respect to the completeness or accuracy in the coverage of the programs described in this list nor for their success in doing the calculations that are reported. It has been a formidable task to assemble this list, and we wish to thank the many contributors who have supplied information on programs with which we have had no direct experience. Some of the programs may have been misclassified and some may have codes misassigned, but without first-hand experience, it is difficult to be perfect. World-wide coverage has been the goal of this project, but some geographic regions are probably under reported. One hopes that the next list will be more nearly complete.

Although this list has been compiled under the auspices of the International Union of Crystallography and its Commission on Powder Diffraction, these bodies disclaim any responsibility for the effectiveness or availability of the programs listed. No endorsement of any program is implied by its inclusion in this list. 
Table 1. Codes used in the program lists

Program language

$\begin{array}{llll}A & \text { Assembly } & \text { GWB } & \text { GW Basic } \\ \text { Alg } & \text { Algol } & P & \text { Pascal } \\ B & \text { Basic } & \text { QB } & \text { Quick Basic } \\ C & \text { C } & \text { TB } & \text { Turbo Basic } \\ F & \text { Fortran IV, 77, ANSI } & \text { TC } & \text { Turbo C } \\ \text { GFA } & \text { Atari } & \text { TP } & \text { Turbo Pascal }\end{array}$

\section{Computer type}

$\begin{array}{lll}\text { MF } & \text { Main-frames } & \text { CDC, Cray, IBM, PDP, VAX } \\ \text { PC } & \text { Personal computer } & \text { IBM, MAC } \\ \text { TS } & \text { Time-sharing } & \\ O & \text { Other types } & \text { ENCORE, FACOM, PRIME }\end{array}$

Distribution form of program codes

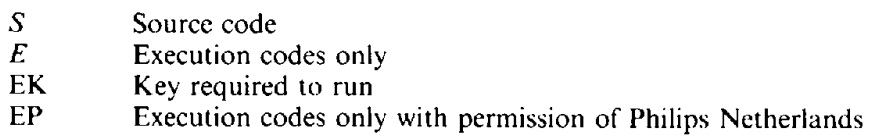

Costs and conditions for distribution of codes

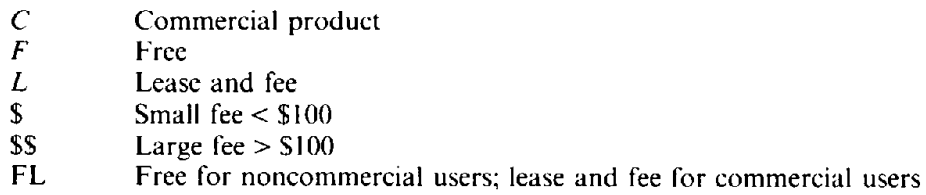

Type of documentation

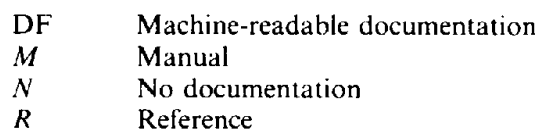

Program support

$\begin{array}{ll}A & \text { Author support } \\ N & \text { No support } \\ \text { Blank } & \text { No indication }\end{array}$

Program sources

PEB Program is available from the Powder Diffraction Software Exchange Bank of the Dutch Association of Crystallographers.

* Source address or reference not available

OLD An old program available from many sources

\section{Introduction}

This list of computer programs for powder diffraction analysis of materials, prepared at the request of the International Union of Crystallography Commission on Powder Diffraction, is an update to the list prepared for the Mineralogical Society of America as part of their Short Course on Modern Powder Diffraction (Smith, 1989) augmented by contacting all the identified program authors with a standard form to increase the database of descriptive information and correct any misrepresentations. Many new programs have also been added. Most new programs were located by contacts made at meetings and through the literature. Each new program author was requested to supply the same information on the standard form to supplement the database. This list will never be complete because powder diffraction is a very dynamic field and new programs are being prepared all the time. Many of the listed programs continue to be revised and upgraded as new ideas occur to the program author and users supply suggestions. It is impossible to keep up with all these changes. This list may be revised and reprinted about every two years if there is sufficient interest and program authors continue to supply information to maintain the database.

The selection of programs for this listing has not been limited to software which is distributed free or with a small distribution charge. Commercial soft- 
ware has been included where the program is distributed independently of a package including hardware. This decision is based on several factors. First, the main purpose of this list is to disseminate information to potential users as to where they may acquire the necessary software to meet their specific needs. Second, although free software used to be the norm in the scientific society, times have changed. The cost of programming is rarely supported in modern research and analysis and computers have become so sophisticated that good programming requires time and effort of a specialist. Third, the commercial program is usually more refined and easier to use. The proportion of free programs is higher for mainframe computers than for personal computers also. Part of the reason for this situation is that many of the $\mathrm{PC}$ routines are conversions of programs which were first developed for main-frames. These conversions are usually done by entrepreneurs taking advantage of the change of our computing base from the main-frame to the PC. This trend will continue for the foreseeable future. The program list indicates the type of computer for which the program is intended.

This program list is divided into general categories based on the type of calculation being performed and the nature of the data being analysed. The categories are generally recognized stages in powder diffraction analysis such as phase identification, indexing of a data set, phase quantification, structure refinement etc. All older programs used discrete $d$ spacings and intensities, but many of the recent programs work directly on the digitized raw diffraction trace. Within each category, there is no effort to rank or evaluate programs. That decision is up to the user. The publication authors have not had experience with every program in the list so such an evaluation would be impossible. For a specific laboratory, only one program from a specific category, such as Rietveld analysis, might be sufficient, whereas from other categories, such as phase identification or indexing, several programs would be desirable where the results from each could be compared. There is a descriptive paragraph with each category listing which may assist the beginner in selecting programs but, in general, the discussions will not promote any specific program.

The information in the list accompanying each program entry indicates the programming language, the nature of the code which will be distributed, any costs involved, information on documentation and whether the program author will support the code. The meaning of the various symbols is listed in Table 1. The program author or other source for obtaining copies of the program are listed in the last column. This entry may refer to an address for requesting the program or to a reference which will have more information. The addresses are listed in the Appendix under the program author or company name. Every effort has been made to make this list accurate, but the publication authors disclaim any responsibility for errors that might exist. All errors should be brought to the attention of the publication authors for correction in subsequent lists.

\section{Program descriptions}

\section{Crystallographic databases}

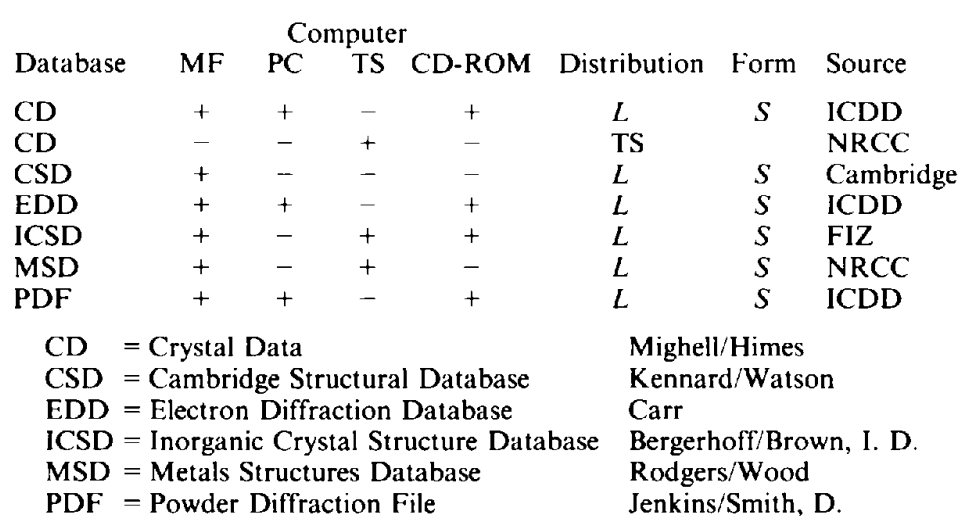

Although the Powder Diffraction File has been the primary source of powder-diffraction-pattern information for over 50 years, there are several other databases that are very important for modern analyses. The assembling, editing and maintenance of large databases is not a simple undertaking. The time required dictates that the operation is full-time, usually involving several individuals. Support for the operations varies with some being totally dependent on the sales of the database and others receiving some federal and industrial financial assistance. Even with the subsidies, the costs of operating databases 
require that the distribution of the data be controlled through legal agreements that restrict the copying of the data and use by third parties. Regardless of the costs, the value of the information in these databases makes them a necessity in the package of computer programs for data analysis in almost every laboratory.

The Powder Diffraction File, PDF, contains selected $d$-spacing and intensity patterns for over 50000 inorganic and organic compounds along with supporting crystallographic and reference information. These data sets are the basis for phase identification and characterization. Crystal structure descriptions are the main information in the Inorganic Crystal Structure Database ICSD, the Metals Structure Database MSD and the Cambridge Siructural Database CSD. For the powder diffractionist, these descriptions may be starting data sets for calculating powder diffraction patterns or for Rietveld refinements. Crystal Data, CD, is a compendium of unit-cell information with over 149000 entries. If the cell parameters of a compound are known, the compound may be identified using this database. It is also an excellent resource for literature references by looking up specific compounds. The Electron Diffraction Database, EDD, is a derivative of the PDF and CD which uses the crystallographic data to calculate diffraction patterns appropriate to electron diffraction.

Among these databases, only the PDF is fully available in hard-copy form. Most of them have some derivative products in book form, but not the full database. All these databases are now available in computer-readable form. In fact, all the operations consider the computer-readable product as the primary goal and hard-copy forms may soon disappear completely. Some of the databases are available through on-line subscription services but the costs of connection usually limit the utility of this method of use. All the databases are distributed by lease on magnetic media and, with the increasing interest in CD-ROM, most of the databases are now available on this medium. Manufacturers of automated powder diffractometers, APD, usually incorporate the PDF in their software package and will probably start including the other databases as soon as software is developed around their use.

\section{Analysis packages}

\begin{tabular}{|c|c|c|c|c|c|c|c|c|}
\hline \multirow[b]{2}{*}{ Program } & \multicolumn{3}{|c|}{ Computer } & \multirow[b]{2}{*}{ Form } & \multirow[b]{2}{*}{ Cost } & \multirow[b]{2}{*}{ Support } & \multirow[b]{2}{*}{ Documentation } & \multirow[b]{2}{*}{ Source } \\
\hline & Language & $\mathrm{MF}$ & PC & & & & & \\
\hline$A T A R I$ & $B$ & - & + & $E$ & $F$ & $A$ & DF & Melzer \\
\hline AUTO & $F$ & + & - & $s$ & $F$ & $A$ & DF & Snyder \\
\hline CRYSTALS & $F$ & + & - & & $\$ \$$ & $A$ & & Watkin \\
\hline $\operatorname{CSD}$ & $F$ & + & + & $S$ & $C$ & $A$ & $M$ & Tsytsenko \\
\hline DIFFRACTINEL & $F, A$ & - & + & $E$ & $C$ & $A$ & $M$ & INEL \\
\hline GSAS & $F$ & + & - & $E$ & $F$ & $A$ & $\mathrm{DF}$ & Larsen/Von Dreele \\
\hline$N R C / V A X$ & $F$ & + & - & $S$ & $\$$ & $A$ & DF & Gabe \\
\hline PATCOM & $C, F, P$ & - & + & $S$ & C & $A$ & DF & Cherner \\
\hline$P C / N R C$ & $F$ & - & + & $S$ & s & $A$ & $\mathrm{DF}$ & White \\
\hline SHELXS-86 & $F$ & + & - & $S$ & $F$ & $A$ & $M$ & Sheldrick \\
\hline SHELXTL-Plus & $F, A$ & + & - & $E$ & $C$ & $A$ & DF & Sheldrick \\
\hline SHELXTL/PC & $F, A$ & - & + & E & 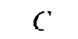 & $A$ & DF & Sheldrick \\
\hline$S / R 88$ & $F$ & + & - & $S$ & & $A$ & DF & Burla \\
\hline TEXSAN & $F$ & + & - & $S$ & C & $A$ & DF & TEXSAN \\
\hline$X P A S$ & $B$ & - & + & $S$ & $F$ & $A$ & $M$ & Singh/Gilkes \\
\hline$X T A L$ & $F$ & t & - & $S$ & & $A$ & $M$ & Hall/Stewart \\
\hline ZEOPAK & $F$ & + & - & $S$ & $\$ \$$ & $A$ & DF & Johnson, G./Smith \\
\hline
\end{tabular}

Although the main purpose of this list is to identify individual programs, there are several packages of programs which include many of the individual programs of interest to powder diffractionists. All APD manufacturers have a package of analytical programs which accompany their data-collection software, but they do not make the package available without the purchase of the hardware. $A U T O$, $D I F F R A C T I N E L$ and $Z E O P A K$ are packages speci- fically designed for powder applications which are independent of hardware and a new user would be advised to look into starting with such a package. All the other packages on this list are designed primarily for the single-crystal diffractionist, but they do contain some of the 'powder' programs. These packages vary considerably in cost to the user and in ease of implementation. It would be advisable to contact the program authors for more information. 


\section{Instrument control and data processing}

\begin{tabular}{|c|c|c|c|c|c|c|c|c|c|}
\hline \multirow[b]{2}{*}{ Program } & \multicolumn{4}{|c|}{ Computer } & \multirow[b]{2}{*}{ Form } & \multirow[b]{2}{*}{ Cost } & \multirow[b]{2}{*}{ Support } & \multirow[b]{2}{*}{ Documentation } & \multirow[b]{2}{*}{ Source } \\
\hline & Lang & guage & $\mathrm{MF}$ & $\mathrm{PC}$ & & & & & \\
\hline$A B S C Y L$ & $\mathrm{FM}^{*}$ & $F$ & + & - & $S$ & $F$ & $A$ & DF & Helmholdt/PEB \\
\hline$++A D M++$ & & & - & + & $S$ & $L$ & $A$ & $M$ & Wassermann/Lorenz \\
\hline$A D R$ & DC & $F$ & + & - & $S$ & $F$ & $A$ & DF & Mallory/Snyder \\
\hline AUTOPEAK & PF & $F$ & + & - & $S$ & $F$ & $A$ & DF & RAL \\
\hline$B A C K E R$ & FM & $F$ & + & - & $S$ & $F$ & $A$ & DF & RAL \\
\hline$B K G R D$ & FM & $F$ & + & - & $S$ & $\$ \$$ & $A$ & DF & Smith, D. \\
\hline$C A L I B E R / V A X$ & FM & $F$ & + & - & $S$ & $F$ & $A$ & DF & Hubbard \\
\hline$C A L I B R / 90$ & FM & $F$ & - & + & $E$ & $\$$ & $A$ & DF & Hubbard \\
\hline COMPOUND COR & FM & $F$ & + & - & EP & FL & $A$ & DF & Jansen/PEB \\
\hline CONTAIN C & FM & $F$ & + & - & EP & FL & $A$ & DF & Jansen/PEB \\
\hline$D E L R E F$ & FM & $F$ & + & - & EP & FL & $A$ & DF & Jansen/PEB \\
\hline DIFFRAC & PF & TP & - & + & $S$ & $F$ & $A$ & DF & Allman/PEB \\
\hline DIFFRACT-AT/BASIC & $\mathrm{DC}$ & $F, A$ & - & + & $E$ & $C$ & $A$ & $M$ & Socabim \\
\hline$D R X$ & DC & QB & - & + & $E$ & $F$ & $N$ & $M$ & Vila (1) \\
\hline ECN TO PHILIPS & FM & $F$ & + & - & EP & FL & $A$ & DF & Jansen/PEB \\
\hline EXCHANGE & FM & $F$ & + & - & $E$ & $C$ & $A$ & DF & Socabim \\
\hline GUFI & FR & $F$ & + & + & $E$ & $\$ \$$ & $A$ & $M$ & Dinnebier/Eysel \\
\hline$I N T C A L$ & FM & $F$ & + & - & $S$ & $F$ & A & DF & Snyder \\
\hline I.S.I.P. & DC & TB & - & t & $E$ & $F$ & $A$ & $R$ & Rogers/Lane \\
\hline$J C A M P-D X$ & FM & $B$ & + & + & $S$ & $C$ & $A$ & $M$ & McDonald/Wilks \\
\hline$J C A M P \cdot P D F$ & FM & $F$ & + & - & $S$ & $F$ & $A$ & DF & Toby $/$ PEB \\
\hline LATCO & PF & $\mathrm{TP}, F$ & - & t & $S$ & $F$ & $A$ & DF & Allman/PEB \\
\hline MicroPEAK & PF & $F$ & - & + & EK & $C$ & $A$ & $M$ & Johnson, Q. \\
\hline$P D F 2$ & DC & $B$ & - & + & $S$ & $F$ & $A$ & DF & Allman/PEB \\
\hline PEAK & PF & $F$ & + & - & $S$ & $F$ & $A$ & DF & Sonneveld/Visser/PEB \\
\hline$Q U A S A R$ & FM & $F$ & + & - & $S$ & $F$ & $A$ & DF & Hall/PEB \\
\hline REBIN RD & $\mathbf{F M}$ & $F$ & + & - & EP & FL & $A$ & DF & Jansen/PEB \\
\hline$R D T O A S C I I$ & FM & $F$ & + & - & EP & FL & $A$ & DF & Jansen/PEB \\
\hline$S C A L E R D$ & FM & $F$ & + & - & EP & FL & $A$ & DF & Jansen/PEB \\
\hline$S C A N$ & FR & $\mathrm{TP}, F$ & + & + & $S$ & $c$ & $A$ & DF & Eriksson \\
\hline SCANPI & FR & $F$ & + & + & $S$ & C & $A$ & DF & Werner \\
\hline SPECPLOT & PF & $F$ & + & - & $S$ & $F$ & $N$ & $M$ & Goehner \\
\hline VAXCON & FM & $F$ & + & - & $S$ & $F$ & $A$ & DF & Zhou/Snyder \\
\hline ZERO SHIFT & FM & $F$ & + & - & EP & FL & $A$ & DF & Jansen/PEB \\
\hline
\end{tabular}

Before one can interpret data, one must collect it. All the APD manufacturers supply the datacollection software with their hardware, but there are many programs written for situations where the laboratory is automating their own hardware. The big trend in instrument control is towards the $\mathrm{PC}$ as the control computer both from the lower cost to the laboratory and the ease of using the PC as a standalone system. The capabilities of the PC have improved in capacity and speed so that it can eliminate the dependence of the laboratory on the central computer facilities for both instrument control and data analysis.

The programs which fall in the category of data collection and data processing may be subdivided into sections: diffractometer control, film reading, file manipulation and peak finding. These divisions are indicated by DC, FR, FM and PF respectively in the table. Film-reading programs are for processing Guinier films with a densitometer. They contain peak-locating algorithms as well as the densitometer interface. The file-management programs are designed to process digitized diffraction traces either transferring them from one format to another for interinstrument communication or to prepare the file for preliminary analysis such as background stripping and internal standard calibration. The peakfinding packages specifically convert the digitized data to $d$ spacings and associated intensities. Several of these programs are hardware specific, especially the film-reading programs. On the other hand, programs like $J C A M P-D X$ and $V A X C O M$ are designed to allow the interpretation of files from many different types of hardware. 
$d$ generation

\begin{tabular}{lcccccccl} 
Program & Language & $\mathrm{MF}$ & $\mathrm{PC}$ & Form & Cost & Support & Documentation & Source \\
d-SPACE & $F$ & - & + & $S$ & $F$ & $A$ & DF & Nickel \\
$G N H K L$ & $F$ & - & + & $S$ & $F$ & $A$ & $M$ & Prewitt \\
Lines-2.0 & $B$ & - & + & $S$ & $F$ & $A$ & DF & de Graff/PEB \\
$X R D$ & $F$ & + & + & $S$ & $F$ & $A$ & DF & Kimmel \\
& \multicolumn{7}{c}{ (Many others including indexing routines.) } &
\end{tabular}

Probably the single most common program in powder analysis is the generation of the $d$ spacings given a specific crystallographic unit cell. There are so many versions that it would be fruitless to try and locate them all. What is included in the list are routines which were mentioned on the questionnaires supplied to obtain the other information in this report. Many of the other programs listed under other categories in this report contain $d$-spacing generators as part of the general calculation. All the indexing and cell-refinement programs generate $d$ spacings and so do the intensity-calculating programs. Also, it is relatively easy to program the readily available pocket calculators to do this calculation.
Perhaps it is appropriate to mention here that there are also many programs which will prepare tables of angle-to- $d$-spacing conversions and perform other simple calculations. Although these tables are essentially made obsolete by the peak-finding procedures, there is still occasional need to check graphical plots for the corresponding $d$ values. This calculation is easy to program on the pocket calculator or to add to any working package. However, the utility of having a package of these simple programs on the laboratory computer is not to be underestimated. The publication authors have often used a collection of small programs to calculate crystal densities, absorption coefficients, compound weight percents, equivalent Miller indices, angles between crystal directions etc.

\section{Graphical $d-I$ display}

\begin{tabular}{|c|c|c|c|c|c|c|c|c|}
\hline \multirow[b]{2}{*}{ Program } & \multicolumn{4}{|c|}{ Computer } & \multirow[b]{2}{*}{ Cost } & \multirow[b]{2}{*}{ Support } & \multirow[b]{2}{*}{ Documentation } & \multirow[b]{2}{*}{ Source } \\
\hline & Language & $\mathrm{MF}$ & $P C$ & Form & & & & \\
\hline MicroDSPACE & $F$ & & + & EK & $C$ & $A$ & $M$ & Johnson, Q. \\
\hline$\mu P D F$ & $F$ & - & + & $E$ & $C$ & $A$ & $M$ & Marquart \\
\hline$P A T C O M$ & $C, F, P$ & - & + & $E$ & $c^{\circ}$ & $A$ & & Cherner \\
\hline PISOT-RD & $F$ & + & - & $S$ & $F$ & $A$ & $\mathrm{DF}$ & Jansen/PEB \\
\hline$P P D P$ & $F, A$ & + & + & $E$ & $\$$ & $A$ & DF & Okamoto Kawahara \\
\hline SIMLL COMBIN & $F$ & + & - & $S$ & SS & $A$ & DF & Smith, D. \\
\hline SPECPLOT & $F$ & + & & $S$ & $F$ & $N$ & $M$ & Gochner \\
\hline$X R A Y P L O T$ & $B$ & . & + & $S$ & $F$ & & $M$ & Canfield \\
\hline
\end{tabular}

Graphical displays of powder patterns from databases or other $d-I$ data sets are a necessity for the visualization of the agreement of experimental data and its interpretation. The diffractionist has most confidence in examining the raw diffraction trace against the diffraction traces of the phases which are most likely to comprise the sample under study. On-screen graphics allow the user to parallel or superimpose the traces for visual matching. Usually, the display used the simplest histogram form for display of the database information pat- terns, but some of the routines on the list use simulated peak shapes from triangles to analytical profiles. The closer the calculated peak shape is to the actual experimental shape, the easier it is to interpret the agreement. Programs involving graphics are often hard to transport because the graphics hardware is so varied, but the calculation routine would be essentially identical. Individuals familiar with PC graphics could adapt any of the free routines to almost any situation. 


\section{Phase identification}

\begin{tabular}{|c|c|c|c|c|c|c|c|c|}
\hline \multirow[b]{2}{*}{ Program } & \multicolumn{3}{|c|}{ Computer } & \multirow[b]{2}{*}{ Form } & \multirow[b]{2}{*}{ Cost } & \multirow[b]{2}{*}{ Support } & \multirow[b]{2}{*}{ Documentation } & \multirow[b]{2}{*}{ Source } \\
\hline & Language & MF & $\mathrm{PC}$ & & & & & \\
\hline$A F P Y / A F P B$ & $F$ & + & - & $S$ & $F$ & $A$ & $R$ & Fiala \\
\hline$D C 26$ & $F$ & - & + & $S$ & $F$ & $A$ & $M$ & Fiala \\
\hline$D I F F R A C-A T / S E A R C H$ & $F . A$ & - & + & $E$ & $C$ & $A$ & $M$ & Socabim \\
\hline$F A Z, A N$ & F.P & - & + & $S$ & $\$ \$$ & $A$ & $\mathrm{DF}$ & Burova \\
\hline FSRCH & $F . A$ & + & - & $S$ & $F$ & $A$ & $M$ & Carr \\
\hline JOHNSON VAND & $F$ & + & - & $S$ & $F$ & $A$ & DF & Johnson, G. \\
\hline MicrolD & $F$ & - & + & EK & C & $A$ & $M$ & Johnson, Q. \\
\hline$\mu P D S M$ & $F . A$ & - & + & $E$ & $C$ & $A$ & $M$ & Marquart \\
\hline$++P A D S++$ & & + & - & $E$ & $C$ & $A$ & $M$ & Wassermann \\
\hline POWDER SUITE & $F . A$ & + & - & $S$ & $F$ & $A$ & $\mathrm{DF}$ & Toby Harlow \\
\hline PRIDENT & $F$ & + & - & $S$ & $F$ & $N$ & $R$ & Garbauskas \\
\hline$S E A R C H$ & $F$ & - & + & $E$ & C & $A$ & $R$ & Sietronics \\
\hline$S E A R C H / M A T C H$ & $F$ & + & & $S$ & & $A$ & $R$ & Lin \\
\hline$W A I T$ & $F$ & - & + & $E$ & $\$ \$$ & $A$ & $M$ & O'Connor \\
\hline$X R D Q U A L$ & $F$ & + & - & $S$ & $F$ & $N$ & DF & Clayton/PEB \\
\hline$X R D C S / M S$ & $F$ & + & + & $E$ & $\$ \$$ & $A$ & $M$ & O'Connor \\
\hline ZRD/SEARCH & $F$ & + & - & $S$ & $\$ \$$ & $N$ & $R$ & Siemens \\
\hline
\end{tabular}

Identification of phases by comparing the experimental set of $d$ 's and $I$ 's against the patterns in a database such as the PDF is probably the single most used application of powder diffraction. As soon as computers became well established in the early 1960 's, programs were written to accomplish this goal. Numerical matching of extended data sets is tedious for individuals, so it is natural that computers be employed to perform the main task of searching the database. The problem increases in difficulty as the size of the databases continues to grow. The goal of search programs is to scan the full reference database selecting the phases with the highest probability of comprising the unknown phase. With simple problems or with luck, the complete answer can be located, but usually the problem is complex and the program can only rank the answers based on some algorithm and present the table of candidates to the user for the final decision. All of the programs available today use this philosophy.

Among the many search programs that are available, no two use exactly the same search strategy. Because the computer is tireless, a trial-and-error approach is feasible. Essentially every pattern in the database is tested during each run using prescreening or specifically ordered data files to minimize the number of steps involved. The basic question asked of each pattern is what is the probability of the reference pattern being contained in the pattern of the unknown. Some figure of merit is assigned the pattern and in the final presentation a list of candidate phases is presented ranked on the figure of merit. The most successful programs are not always the ones that run the fastest.

All the search programs contain routines that allow the user to evaluate the candidate phases by matching the $d-I$ data sets with the experimental data. This step is known as the match step and is always necessary to evaluate the search candidates. This comparison may be numerical or it may be graphical involving some of the displays described in the previous section. Numerical matching is often less convincing because the small $d$-spacing errors require numerical windows for proper alignment.

Because search programs are so different in their procedures of manipulating experimental data, their success also varies considerably. There are often many tricks to getting the best results which come from long experience with a specific program. Program authors always have more success than casual users. Typically, users find one program to their liking, often based on some early successes, and then never try any of the other routines. Probably the best procedure is to employ two or three of these routines on complex problems and compare the different results to determine the best answer. Comparison of programs is made easier by set-up programs that take the standard $d-I$ data set from the peak-finding routine and prepare the input files in the proper formats for the specific search programs. Such set-up routines are only available in packages where several search programs are used. Users can write their own set-up programs, and the time will usually be well spent. 
Automatic indexing

\begin{tabular}{|c|c|c|c|c|c|c|c|c|}
\hline \multirow[b]{2}{*}{ Program } & \multicolumn{4}{|c|}{ Computer } & \multirow[b]{2}{*}{ Cost } & \multirow[b]{2}{*}{ Support } & \multirow[b]{2}{*}{ Documentation } & \multirow[b]{2}{*}{ Source } \\
\hline & Language & $\mathrm{MF}$ & $\mathrm{PC}$ & Form & & & & \\
\hline$A I D E D$ & $F$ & + & - & & & & $R$ & Setten \\
\hline$D E L A U N A Y$ & $F$ & + & - & $S$ & $F$ & $A$ & DF & Gorter/PEB \\
\hline DICVOL & $F$ & + & - & $S$ & $F$ & $A$ & DF & Louër/PEB \\
\hline DICVOL 90 & $F$ & + & - & $S$ & $F$ & $A$ & DF & Louër \\
\hline GOEBELWWILSON & $F$ & + & - & $S$ & $F$ & & $R$ & OLD/PEB \\
\hline ITO & $F$ & + & + & $S$ & $F$ & $A$ & DF & Visser/PEB \\
\hline$K O H L$ & $F$ & + & + & $S$ & $\$$ & $A$ & $R$ & Kohlbeck/PEB \\
\hline LINES 2.0 & GFA & - & + & $S$ & $\$$ & $A$ & $M$ & de Graaff/PEB \\
\hline MicroINDEX & $F$ & - & + & EK & $C$ & $A$ & $M$ & Johnson, Q. \\
\hline POWDMULT & $F$ & + & + & $S$ & $\$$ & $A$ & DF & Wu \\
\hline$P W D C D S(P O W D E R)$ & $F, A$ & + & + & $S$ & $F$ & $A$ & $R$ & Taupin/PEB \\
\hline$S C A N I X 2.0$ & $F$ & - & + & $E$ & $\$$ & $S$ & DF & Paszkowicz \\
\hline$T R A N S F O R$ & $F$ & + & - & $S$ & $F$ & $A$ & $\mathrm{DF}$ & Gorter/PEB \\
\hline TREOR-5 & $F$ & + & + & $S$ & $F$ & $A$ & DF & Werner \\
\hline TREOR-90 & $F$ & + & -- & $S$ & $F$ & $A$ & DF & Werner/PEB \\
\hline
\end{tabular}

With the increased accuracy of the data obtainable from the APD, indexing procedures are becoming more successful. Although indexing procedures date back to the 1960 's, the more sophisticated routines were started in the 1970's, and there has been a recent rejuvenation of interest and improvement in these programs. All of the early programs were written for main-frame computers, but the current programs are being directed towards the PC. Most of the major routines are now available in $\mathrm{PC}$ form. The main-frame programs are all free, but the PC versions are not.

The programs fall into two broad classes depending on whether they use trial-and-error methods or analytical methods as the basis of the calculations. Trial-and-error methods assume a specific crystal system and attempt to fit the data to the indexing equation for that crystal system. Large $d$ spacings are used as guides to initial cell-parameter selections. Analytical methods assume the crystal is triclinic, then examine the lattice for higher symmetry. The more successful routines use limitations such as cell size or cell volume to keep the calculations in bounds. Some of the programs are, by design, more successful with specific crystal systems; no single program is truly universal in its application. It is best for the user to have at least three indexing routines available and perhaps as many as five.

The single most important factor which controls the success of indexing regardless which routine is employed is the accuracy of the data. Accuracy means that the data are measured to angle errors of less than $0.032 \theta$ and that the data have been corrected for systematic diffractometer errors. With this accuracy, the success rate is around $90 \%$. Optimal indexing usually uses 20 to 30 low-angle peaks, but some high-symmetry cells can be solved with fewer peaks. Some users give up when indexing does not solve all their problems, but this result is not a good criterion as some unit cells are unusual with extremely long axes in one direction or pseudosymmetric which makes a solution difficult even with perfect data. The best success is often achieved by comparing the results of several indexing trials with different programs. Where the same answer is reached by several programs, success is usually assured. However, sometimes derivative cells are located and further tests are needed. That is where cell reduction routines to be described below under metric analysis are useful.

\section{Refinement/indexing}

\begin{tabular}{|c|c|c|c|c|c|c|c|c|}
\hline \multirow[b]{2}{*}{ Program } & \multicolumn{4}{|c|}{ Computer } & \multirow[b]{2}{*}{ Cost } & \multirow[b]{2}{*}{ Support } & \multirow[b]{2}{*}{ Documentation } & \multirow[b]{2}{*}{ Source } \\
\hline & Language & $\mathrm{MF}$ & $\mathrm{PC}$ & Form & & & & \\
\hline$A P P L E M A N$ & $F$ & + & - & $S$ & $F$ & $N$ & DF & Appleman PEB \\
\hline$I N D E X I N G$ & $B$ & - & + & $S$ & $F$ & & $R$ & Novak/Colville \\
\hline$\angle A P O D$ & $F$ & + & & $S$ & $F$ & $A$ & $R$ & Langford \\
\hline LSCURI/PC & TP & - & + & $S$ & $F$ & $A$ & $\mathrm{DF}$ & Garvey \\
\hline$L S Q 85$ & $F$ & + & $\cdots$ & $S$ & $F$ & $A$ & DF & Hubbard/PEB \\
\hline$L S Q 90 / P C$ & $F$ & - & + & $E$ & $\$$ & $A$ & $\mathrm{DF}$ & Hubbard \\
\hline$\angle S Q 90 / V A X$ & $F$ & - & + & $S$ & $F$ & $A$ & $\mathrm{DF}$ & Hubbard \\
\hline$N B S^{*} L S Q 85$ & $F$ & + & - & $S$ & $F$ & $A$ & $M$ & Mighell \\
\hline PCIAPPLEVANS & $F$ & - & + & $S$ & $F$ & $N$ & $M$ & Benoit \\
\hline PCPIRUMF & + & + & $S$ & $F$ & $A$ & $R$ & Werner/Er & esson \\
\hline POWD/MULT & $F$ & + & + & $S$ & $\$$ & $A$ & DF & $\mathrm{Wu}$ \\
\hline$P P L P$ & $F$ & + & - & $S$ & $\$$ & $A$ & $\mathrm{DF}$ & Gabe \\
\hline
\end{tabular}


Where a cell is already known, it can be used as the starting point for indexing the pattern. For highsymmetry compounds, such indexing is usually trivial, but for low-symmetry compounds, this is not often the case. One can usually assign Miller indices to the low-angle peaks with confidence but not the high-angle peaks. Refinement/indexing programs use the philosophy that the low-angle peaks can be used to improve the cell parameters which can then be used to index the higher-angle lines. This procedure can be iterative to index all the peaks in the pattern. The APPLEMAN program, written in the late 1950's is the best known of these programs, and all the other programs in this category are derivatives of this routine.

\section{Refinement/error analysis}

\begin{tabular}{|c|c|c|c|c|c|c|c|c|}
\hline \multirow[b]{2}{*}{ Program } & \multicolumn{4}{|c|}{ Computer } & \multirow[b]{2}{*}{ Cost } & \multirow[b]{2}{*}{ Support } & \multirow[b]{2}{*}{ Documentation } & \multirow[b]{2}{*}{ Source } \\
\hline & Language & $\mathrm{MF}$ & $\mathrm{PC}$ & Form & & & & \\
\hline ARGONNE/B-106 & $F$ & + & - & $S$ & $F$ & $N$ & $R$ & Mueller/PEB \\
\hline$E X D I F$ & $F$ & + & + & $S$ & $F$ & $A$ & DF & Kimmel \\
\hline FINAX & $F$ & - & + & $S$ & $\$ \$$ & $A$ & DF & Hovestreydt \\
\hline$L C L S Q-8 \cdot 2$ & $F$ & + & + & $S$ & $\$$ & $A$ & $M$ & Burnham/PEB \\
\hline$\angle U P I N / L O O P Y$ & $F$ & + & - & $S$ & $F$ & $A$ & DF & Brown, A. \\
\hline Micro-CELLREF & $F$ & - & + & EK & C & $A$ & $M$ & Johnson, Q. \\
\hline$P C / C E L R F$ & $B$ & - & + & $S$ & $F$ & $A$ & $M$ & Prewitt \\
\hline PODEX & $F$ & + & - & $S$ & $F$ & & DF & Foris \\
\hline POWDRFIT & $F$ & - & + & $S$ & $F$ & $N$ & DF & Caillat/Bartell \\
\hline
\end{tabular}

The problem with refinement coupled with indexing is that there is no way to include error analysis because drift would occur in the data matching as the indexing proceeds to higher angles. To include error analysis, all the Miller indices must be assigned prior to the calculation. Then, an error function can be included with the calculation. Actually, it is not necessary to know the error a priori because several errors can be tried, and the best-fit data results can indicate the most probable error. The oldest of these programs is $A R G O N N E / B-106$ and the other programs essentially follow this routine.

Because this calculation is mathematical rather than trial and error in nature, it is not necessary to have more than one routine in one's analysis package. All of the listed routines are essentially equivalent.

\section{Metric analysis}

Program
BOOLEAN/LATTICE
CREDUC
EDDIUNITCELL
GEOMSTDV
GEORING
LEPAGE
MISSYM
NBS AIDS $^{*} 3$
NEWLAT
NIST $S E A R C H$
NIST $L A T T I C E-90$
POWABS
PC/R/TRUEBLOOD
REDUCT
SGROUP
TABLES
TRACER-II
VOLUM

\begin{tabular}{cccc}
\multicolumn{5}{c}{ Computer } \\
Language & MF & PC & Form \\
$F$ & + & - & $S$ \\
$F$ & + & - & $S$ \\
$F$ & + & - & $S$ \\
$F$ & + & - & $S$ \\
$F$ & + & - & $S$ \\
TB & - & + & $E$ \\
$F$ & + & - & $S$ \\
$F$ & + & + & $S$ \\
$F$ & + & - & $S$ \\
$F$ & + & - & $S$ \\
$F$ & + & - & $S$ \\
$F$ & + & - & \\
$F$ & - & + & $S$ \\
$F$ & + & + & $S$ \\
$F$ & + & - & $S$ \\
$F$ & + & - & $S$ \\
$F$ & + & - & $S$ \\
$F$ & + & - & $S$
\end{tabular}

Cost
$F$
$F$
$F$
$F$
$F$
$F$
$F$
$F$
$F$
$F$
$F$

$F$
$F$
$F$
$F$
$F$
$F$

One of the problems of powder diffraction determinations of the unit cell is that the symmetry is not observed directly. The symmetry is implied by the lattice geometry determined by the indexing procedure. All lattices have alternative ways of

$\begin{array}{cl}\text { Documentation } & \text { Source } \\ \text { DF } & \text { Johnson, G. } \\ \text { DF } & \text { Gabe } \\ \text { DF } & \text { Himes/Mighell } \\ \text { DF } & \text { Rutten/PEB } \\ \text { DF } & \text { Gorter/PEB } \\ \text { DF } & \text { Spek/PEB } \\ \text { DF } & \text { Gabe } \\ M & \text { ICDD/PEB } \\ \text { DF } & \text { Mugnoli } \\ M & \text { Himes/Mighell } \\ M & \text { Himes/Mighell } \\ R & \text { Byrom/Lucas } \\ M & \text { Blanchard } \\ \text { DF } & \text { Westdahl/Werner } \\ & \text { Yerkess/PEB } \\ \text { M } & \text { Abad-Zapatero/ODonnell } \\ \text { DF } & \text { Lawton } \\ \text { DF } & \text { Bosman/PEB }\end{array}$

describing the same periodicity, and the true symmetry must be determined by further tests such as optical properties. There are mathematical tests that check lattices for higher symmetries and centred lattice types. These calculations involve reducing the 
lattice to a cell following specific rules then examining that cell for parameter relations. Most of the programs listed under metric analysis do this cell reduction.

Once the reduced cell and probable highestsymmetry lattice is identified, the cell information may be used to identify the material. Crystal data are a compendium of unit-cell data, and they can be used for numerical cell comparisons to locate all compounds that have similar cells. Because of the many ways possible to describe the same lattice even in the same crystal system, rules must be followed both for the database and for the cell to be matched. Also, because of the chance that the true cell is a multiple of the observed cell, super- and subcells must also be considered. The program NIST*
$S E A R C H$ is used to interrogate the CD database while testing all the possibilities. With a database the size of $C D$, metric searching is a powerful technique for identification where other identification procedures have failed.

MISSYM is a metric- and symmetry-analysis routine for interrogating single-crystal structure information for missing symmetry. Many times single-crystal structures are solved using direct computer methods with no lattice-symmetry information determined by film studies. Consequently the structure may be solved in the wrong space. MISSYM examines the atom coordinates as well as the lattice for missed symmetry elements and suggests alternative space groups and lattice descriptions.

\section{Pattern generation}

\begin{tabular}{|c|c|c|c|c|c|c|c|c|}
\hline \multirow[b]{2}{*}{ Program } & \multicolumn{4}{|c|}{ Computer } & \multirow[b]{2}{*}{ Cost } & \multirow[b]{2}{*}{ Support } & \multirow[b]{2}{*}{ Documentation } & \multirow[b]{2}{*}{ Source } \\
\hline & Language & $\mathrm{MF}^{+}$ & PC & Form & & & & \\
\hline DISPOW & $F$ & + & - & $S$ & $F$ & $A$ & $\mathrm{DF}$ & Gabe \\
\hline$E D D A(\mathrm{EDX})^{*}$ & $F$ & + & - & $S$ & $F$ & $N$ & $\mathrm{DF}$ & Gerward \\
\hline$E D D A / P C(\mathrm{EDX})$ & $F$ & - & + & $S$ & $F$ & $N$ & $\mathrm{DF}$ & Gerward \\
\hline ENDIX & $F$ & - & + & $S$ & $\$ \$$ & $A$ & $\mathrm{DF}$ & Hovestreydt \\
\hline$I N T$ & $F$ & + & + & $S$ & $F$ & $A$ & $\mathrm{DF}$ & Kaplan/Kimmel \\
\hline INTER (2D) $\dagger$ & QB & - & + & $E$ & $\$$ & $A$ & $M$ & Vila (1) \\
\hline LAZY PULVERIX & $F$ & + & - & $S$ & $F$ & $A$ & $\mathrm{DF}$ & Yvon/PEB \\
\hline LAZY PULVERIX/BROWN & $F$ & + & - & $S$ & $F$ & $A$ & DF & Brown, A. \\
\hline LAZY PULVERIXIPC & $F$ & - & + & $S$ & $F$ & $A$ & $\mathrm{DF}$ & Yvon \\
\hline MicroPOWD & $F$ & - & + & EK & $C$ & $A$ & $M$ & Johnson, Q./Smith, K \\
\hline$M O D 2(2 \mathrm{D})$ & $\mathrm{TB}, F$ & + & + & $S$ & $F$ & $A$ & $M$ & OLD \\
\hline$M O D 88(2 \mathrm{D})$ & TB & - & + & $E$ & $\$ \$$ & $A$ & $M$ & Reynolds \\
\hline PC/POWIN & $B$ & - & + & $S$ & $F$ & $A$ & $M$ & Prewitl \\
\hline$P C / X D P G$ & $\begin{array}{l}D \\
B\end{array}$ & - & + & $E$ & $\$$ & $A$ & & Russ \\
\hline POWD12 & $\begin{array}{l}\boldsymbol{D} \\
F\end{array}$ & + & - & $\stackrel{L}{S}$ & $F$ & $A$ & DF & Smith, D./PEB \\
\hline POWD12+ & $F$ & + & - & $S$ & $\$ \$$ & $A$ & DF & Smith, D. \\
\hline PRECRA YISIMVAX & $F$ & + & - & $S$ & $F$ & $A$ & $R$ & Espinat \\
\hline PROF DET & $F$ & + &.- & $S$ & $F$ & $A$ & DF & PEB \\
\hline SIMULATE (TOF) $\ddagger$ & $F$ & + & - & $S$ & $F$ & $A$ & DF & RAL \\
\hline TOFSIMU & $F$ & + & - & $S$ & $F$ & $A$ & DF & IPNS \\
\hline$X P O W$ & $F$ & + & - & $S$ & $F$ & $A$ & $M$ & Sheldrick \\
\hline$X P S I$ & $F$ & + & + & $S$ & $F$ & $A$ & $\mathrm{DF}$ & Kimmel \\
\hline
\end{tabular}

The best way to interpret the information in a powder diffraction pattern is to calculate the theoretical pattern from the structure model including the diffraction effects. There are many programs which do this calculation, although they have all been derived from either POWD or LAZY PULVERIX which first were written in the 1960's. The calculation of integrated intensities is fairly straightforward starting from the crystal structure description. The $P O W D$ family of programs takes the integrated intensities and creates a diffraction trace by calculating profiles for every peak and adding them to simulate the actual trace. The $P O W D$ program is responsible for most of the calculated powder patterns in the PDF. The peak intensities are reported which are determined from the calculated trace.

One advantage of intensity calculations is the ease of testing possible models of the compounds under study. It is a simple matter to calculate the substitutional effects of replacing one element for another in a structure. Lattice distortions and crystallite size effects may be included. The $00 l$ peaks from twodimensional structures such as clay minerals can be modelled using MOD2 and MOD88. These patterns can be compared to experimental data obtained on deliberately oriented samples. 


\section{Profile fitting - decomposition}

\begin{tabular}{|c|c|c|c|c|c|c|c|c|}
\hline \multirow[b]{2}{*}{ Program } & \multicolumn{4}{|c|}{ Computer } & \multirow[b]{2}{*}{ Cost } & \multirow[b]{2}{*}{ Support } & \multirow[b]{2}{*}{ Documentation } & \multirow[b]{2}{*}{ Source } \\
\hline & Language & MF & PC & Form & & & & \\
\hline$A B F f i t$ & $F, P$ & + & + & $E$ & $\$ \$$ & $A$ & $M$ & Antoniadis \\
\hline$A U T O P E A K$ & $F$ & + & - & $S$ & $F$ & $A$ & DF & RAL \\
\hline CUVFIT & & + & - & & & & & Wang \\
\hline$D I F F R A C T-A T / F I T$ & $F, A$ & - & + & $E$ & $C$ & $A$ & $M$ & Socabim \\
\hline DOREES & $F, P$ & + & - & $E$ & $\$ \$$ & $A$ & DF & Jansen \\
\hline$F I T$ & $\mathrm{TC}$ & - & + & $E$ & $F$ & $A$ & $R$ & Petkov/Bakaltchev/PEB \\
\hline$K E T, K E T A$ & $F$ & - & + & $E$ & $\$ \$$ & $A$ & $M$ & Kogan \\
\hline$L A T 1$ & $F$ & + & - & $S$ & $F$ & $A$ & $R$ & Tran \\
\hline LSQPROF & $F, P$ & + & - & $E$ & $\$ \$$ & $A$ & DF & Jansen \\
\hline MicroSHADOW & $F$ & - & + & EK & $C$ & $A$ & $M$ & Johnson, Q. \\
\hline PEAK & $F$ & + & + & $E$ & $\$ \$$ & $A$ & $M$ & Dinnebier/Eysel \\
\hline PíoPiliPa'a & $F$ & + & - & $S$ & $F$ & $A$ & $M$ & Jones \\
\hline POWDER & & & & & & & & Rossel/Scott \\
\hline POWDERPATTERN & $F$ & + & - & $S$ & $F$ & & $R$ & Hubbard/Pyrros \\
\hline PROFAN & $F$ & + & - & $S$ & $\$$ & $A$ & $R$ & Will \\
\hline PROFANIPC & TP & - & + & $S$ & $F$ & $A$ & $R$ & Merz \\
\hline PROFIT & $F$ & + & + & $S$ & $\$ \$$ & $A$ & $M$ & Sonneveld/Langford \\
\hline PRO-FIT & $F$ & + & - & $S$ & $F$ & $A$ & $R$ & Toraya/PEB \\
\hline REGION & $F$ & + & - & $S$ & & & & Hubbard/Pyrros \\
\hline$S C R A P$ & $F$ & + & - & & & & & Cooper \\
\hline SHADOW & $F$ & + & - & $S$ & $F$ & $A$ & DF & Howard, S./PEB \\
\hline$T O F M A N Y$ & $F$ & + & - & $S$ & $F$ & $A$ & DF & IPNS \\
\hline$T X T P V G T$ & TP & - & + & $S$ & $\$$ & $A$ & DF & Bourniquel \\
\hline$X R A Y L$ & $F$ & + & - & $S$ & $F$ & $A$ & & Zhang/Hubbard \\
\hline
\end{tabular}

\section{Profile fitting - full pattern}

Program
ALLHKL
EDINP
FINAX
FULLPROF
POWLS
PROFIT
WPPF

\begin{tabular}{cccc}
\multicolumn{5}{c}{ Computer } \\
Language & MF & PC & Form \\
$F$ & + & - & $S$ \\
$F$ & + & - & $E$ \\
$F$ & + & - & $S$ \\
$F$ & + & + & $E$ \\
$F$ & + & + & $S$ \\
$F$ & - & + & $S$ \\
$F$ & + & - & $S$
\end{tabular}

$\begin{array}{cc}\text { Cost } & \text { Support } \\ F & A \\ \$ & A \\ \$ & A \\ F & A \\ \$ \$ & A \\ F & N \\ F & A\end{array}$

Documentatio
DF
$R$
$R$
DF
$M$
$M$
DF

Source
Pawley
Pawley
Hovestreydt
Rodriguez-Carvajal
Will
Scott
Toraya

With the availability of accurate digitized diffraction traces, peak analysis is becoming a very popular option for locating peaks and for determining the profile parameters. The terminology of profile analysis is confusing for diffractionists who are starting this type of analysis. The programs in this section are correctly classified as decomposition programs. Each of these programs uses a predetermined profile either defined analytically or learned from an isolated peak to fit all the other peaks in the pattern including the $\alpha_{2}$ component. This procedure is to be distinguished from deconvolution which is a Fourier analysis of the peak shape. There are several ways to approach the problem of decomposition.

First, the peaks can all be considered as independent, and each profile can be fit using free parameters. Usually, the profile shape is fixed and the parameters of peak intensity, profile half-width and peak position are varied. The relative positions of the $\alpha_{1}$ and $\alpha_{2}$ components are known, and their intensity ratios are fixed at $0 \cdot 5$. Where there is a mixture of phases, the peak shape may vary among the phases. If crystallite size is a factor and the crystallite shape is non-spherical, the half-width may vary within the peaks of the same phase. It should be apparent from this discussion that no single program can be optimized for all these options.

The programs listed under the heading Profile futing - decomposition differ from the ones listed under Profile fitting - full pattern in the way the peaks are treated. In the former category, each peak is generally considered as independent of the other peaks even in a cluster, and usually only a limited range of the pattern is considered during each application of the program. In the latter category, all the peaks (or a large number) in the pattern are considered at one time. If the sample is single phase, all the peak positions are related, and the program should constrain the peak locations to those compatible with a unit cell. Usually, the profile shape is also constrained. The purpose of this approach is to resolve individual peaks, so that the intensities can be determined. The single goal of this approach is to 
obtain intensities for crystal structure analysis. These intensities can then be used with the usual singlecrystal analysis programs which employ direct methods and Patterson analysis. All the programs in this section operate on the full pattern to provide individual intensities.

\section{Deconvolution}

Program
CALIBIFITCONVIWAXS
CRYSIZE
DECON
LWL
UNFOLD
WARREN AVERBACH

The diffraction profile contains considerable information on the perfection of the crystallites in the sample. The necessary profile for this information is the sample profile, i.e. the component of the diffraction profile which is due to the sample only. In order to measure this profile it is necessary to remove the instrument and source components. These components must be removed mathematically as there is no way to eliminate them experimentally. The mathematical procedure is called deconvolution.

There are several numerical techniques that have been devised to accomplish the deconvolution mostly based on Fourier transform theory. The numerical

$\begin{array}{ccccl}\text { Form } & \text { Cost } & \text { Support } & \text { Documentation } & \text { Source } \\ S & F & A & M & \text { Enzo/Polizzi } \\ S & F & A & \mathrm{DF} & \text { Zhang/Hubbard } \\ S & F & N & R & \text { Wiedemann } \\ S & \$ & A & R & \text { Louer } \\ S & F & A & \mathrm{DF} & \text { Roof } \\ S & \$ S & A & M & \text { Cohen }\end{array}$

methods are necessary because the profiles cannot be expressed analytically. The methods lead to values of the effective half-width of the sample profile, profile shapes and skewness parameters. If these parameters can be determined as a function of diffraction order, then the strain component can be separated from the size component. In 1950, Warren \& Averbach developed the theory for using multiple orders of peaks to deconvolute the profile into Fourier coefficients. These coefficients are then plotted as a function of the square of the order to obtain the size and strain components.

\section{Crystallinity/strain/texture}

\begin{tabular}{|c|c|c|c|c|c|c|c|c|}
\hline \multirow[b]{2}{*}{ Program } & \multicolumn{4}{|c|}{ Compuler } & \multirow[b]{2}{*}{ Cost } & \multirow[b]{2}{*}{ Support } & \multirow[b]{2}{*}{ Documentation } & \multirow[b]{2}{*}{ Source } \\
\hline & Language & $\mathrm{MF}$ & $\mathrm{PC}$ & Form & & & & \\
\hline CRYSTALLINITY & $F$ & + & - & $s$ & $F$ & $A$ & DF & Jansen PEB \\
\hline POLYMER & $F$ & + & - & $S$ & $F$ & $A$ & DF & Wims \\
\hline$P O P$ & & - & + & & & & & Wenk \\
\hline$R A D$ & $F$ & - & + & $E$ & $F$ & $A$ & DF & Petkov \\
\hline SIZEDIST & $F$ & + & $-\cdot$ & $S$ & $\$$ & $A$ & $R$ & Louër/Lc Bail \\
\hline$S T R E S S-A T$ & $F, A$ & - & + & $E$ & $C$ & $A$ & $M$ & Socabim \\
\hline TEXCAM & TB & - & + & $E$ & $F$ & $A$ & DF & Rogers PEB \\
\hline$W I M V 1$ & & + & + & & & & & Kallend \\
\hline$X T L-S I Z E$ & $F$ & - & + & $S$ & $F$ & $A$ & $R$ & Bonetto PEB \\
\hline
\end{tabular}

There are methods other than Fourier techniques for determining effective crystallite size and size distributions. Most commonly employed is the Scherrer method, which can give a picture of the crystallite shape by analysing the breadths of all the peaks in the pattern. Macrostrain can be measured by detecting peak shifts relative to an unstrained sample. Percent crystallinity can be indicated by the

ratio of the crystalline pattern to the amorphous pattern. Texture can be analysed by following the intensity of specific peaks as a function of the position of the sample with respect to the beam. It was not the plan of this project to locate all the programs that make these measurements, but several were collected during the project which are listed in the table. 


\section{Rietveld - structure refinement}

\begin{tabular}{|c|c|c|c|c|c|c|c|c|}
\hline \multirow[b]{2}{*}{ Program } & \multicolumn{4}{|c|}{ Computer } & \multirow[b]{2}{*}{ Cost } & \multirow[b]{2}{*}{ Support } & \multirow[b]{2}{*}{ Documentation } & \multirow[b]{2}{*}{ Source } \\
\hline & Language & $M F$ & $\mathrm{PC}$ & Form & & & & \\
\hline$A T A L A N T A$ & $F$ & + & - & $S$ & $F$ & $A$ & $R$ & Benham/Ross \\
\hline$C C S L$ & $F$ & + & - & $S$ & & $A$ & DF & RAL \\
\hline$D B W S 9006$ & $F$ & + & - & $S$ & $\$$ & $A$ & $M$ & Young \\
\hline$D B W S 9006 P C$ & $F$ & - & + & $S$ & $\$$ & $A$ & $M$ & Young \\
\hline$E D I N P$ & $F$ & + & - & $E$ & $\$$ & $A$ & $R$ & Pawley \\
\hline$G S A S$ & $F$ & + & - & $E$ & $F$ & $A$ & $M$ & Larson-Von Dreele/PEB \\
\hline FULLPROF & $F$ & + & + & $E$ & $F$ & $A$ & DF & Rodriguez-Carvajal \\
\hline$H I L L /$ Version.90.06 & $F$ & - & + & SE & $\$$ & $A$ & $M$ & Lengauer \\
\hline LHPM-7 & $F$ & + & - & $S$ & $F$ & $A$ & $M$ & Hill/Howard, $\mathbf{C}$. \\
\hline LOOPVELD & $F$ & + & - & $S$ & $F$ & $A$ & $\mathrm{DF}$ & Pawley/PEB \\
\hline MicroRIETVELD & $F$ & - & + & EK & $C$ & $A$ & $M$ & Johnson, $\mathrm{Q}$. \\
\hline MINREF & & + & - & $S$ & & & & Elsenhans/PEB \\
\hline$M O R G U E$ & $F$ & + & - & $S$ & $\$$ & $N$ & $M$ & Byrom/PEB \\
\hline$P C / W Y R I E T$ & $F$ & - & + & $E$ & $\$ \$$ & $A$ & $M$ & Schneider \\
\hline$R I E T A N$ & $F$ & + & - & $S$ & $F$ & $A$ & $R$ & Izumi/PEB \\
\hline RIETVELD & $F$ & + & - & $S$ & $F$ & $A$ & DF & IPNS \\
\hline RIETVELD & $F$ & + & - & $S$ & $F$ & $A$ & DF & ILL \\
\hline RIETVELD & $F$ & + & - & $S$ & $F$ & $A$ & DF & $\mathrm{DL}$ \\
\hline RIETVELD & $F$ & + & - & $S$ & $F$ & $A$ & $\mathrm{DF}$ & RAL \\
\hline$R / E T V E L D$ & $F$ & + & - & $S$ & $F$ & $A$ & DF & Prince \\
\hline RIETVELD & $F$ & t & - & $S$ & $F$ & & & Nurmela \\
\hline$R I E T V E L D$ & $F$ & + & - & $S$ & $F$ & $A$ & $\mathrm{DF}$ & Hewat/Cox \\
\hline$T 53$ & Alg & + & - & $S$ & $F$ & $A$ & DF & Rietveld/PEB \\
\hline$X R S-82$ & $F$ & + & - & $S$ & $F$ & $A$ & $M$ & Bärlocher \\
\hline$X R S-82(V A X)$ & $F$ & + & - & $S$ & $F$ & $A$ & DF & Rudolph/Clearfield \\
\hline
\end{tabular}

The Rietveld method was first introduced in the late 1960's and has become the most versatile technique in powder diffraction analysis. Its primary function is to fit a structure model to the experimental data by calculating the diffraction pattern and using the differences between the calculated and experimental traces to improve the parameters in the model. The refinement procedure is essentially the least-squares method, and the refinement must be approached with caution. There are several levels of sensitivity of the parameters to the experimental data, and the beginner may easily lock into false results. The four main groups of parameters are the scale factors and background, the pattern parameters, the structure-position parameters and secondary parameters such as the temperature factors and orientation effects. The technique has been somewhat more convenient for neutron diffraction where the pattern profile function is more nearly Gaussian, but modern neutron diffractometers with high resolution require the more-complex functions. For the X-ray situation, the choice of profiles has always been a problem, and there are now several options usually employed including Cauchy (Lorentzian), Cauchy-like functions and mixed Cauchy-Gaussian combinations.

The list contains a large number of Rietveld programs which include programs for neutron diffraction as well as X-ray diffraction. It is not possible to single any one program out for general use, but the $D B W S 9006$ and $G S A S$ programs probably are the most widely used. At the present time, the Rietveld programs are undergoing extensive revision in most laboratories where the method is used extensively. Almost all the major neutron and synchrotron facilities in the world are developing their own version of the program. Part of the driving force for these program revisions is the expansion of the method to more than structure refinement. Considerable use is now being made of the pattern parameters for such measurements as crystallite size, strain and phase quantification. 


\section{Quantitative analysis}

\begin{tabular}{|c|c|c|c|c|c|c|c|c|}
\hline \multirow[b]{2}{*}{ Program } & \multicolumn{3}{|c|}{ Computer } & \multirow[b]{2}{*}{ Form } & \multirow[b]{2}{*}{ Cost } & \multirow[b]{2}{*}{ Support } & \multirow[b]{2}{*}{ Documentation } & \multirow[b]{2}{*}{ Source } \\
\hline & Language & MF & $\mathrm{PC}$ & & & & & \\
\hline$A R C O Q U A N T$ & $F$ & + & - & $S$ & $\$ \$$ & $A$ & DF & Smith, D. \\
\hline$D B W-4.1$ & $F$ & + & - & $S$ & $F$ & $A$ & $M$ & Bish/Howard, S. \\
\hline$D B W 3.2 S$ & $F$ & + & - & $S$ & $F$ & $A$ & $M$ & Young \\
\hline$D B W 3.2$ (Modified PEB) & $F$ & + & - & $S$ & $F$ & $A$ & $M$ & Wiles/Young/PEB \\
\hline$F A Z A N$ & $F, P$ & - & + & $S$ & $\$ \$$ & $A$ & $\mathrm{DF}$ & Burova \\
\hline$G M Q U A N T$ & $F$ & + & - & $S$ & $F$ & $A$ & DF & Smith, D./PEB \\
\hline$H O W A R D-2.0$ & $F$ & + & - & $S$ & $F$ & $A$ & $M$ & Howard, S. \\
\hline$L S Q X$ & $F$ & + & + & & $C$ & $A$ & $N$ & Vonk \\
\hline MicroQUANT & $F$ & - & + & $E K$ & $C$ & $A$ & $M$ & Johnson, Q. \\
\hline$++P A D S++$ & $F$ & - & + & $E$ & $C$ & $A$ & & Wassermann \\
\hline$P C / P E A K S$ & $C$ & - & + & $S$ & $C$ & $A$ & $M$ & Hill/Foxworthy \\
\hline$P C / Q X R D$ & $F$ & - & + & $S$ & $\$ \$$ & $A$ & $M$ & Hill \\
\hline$P F L S$ & $F$ & + & - & $S$ & $F$ & $A$ & $R$ & Toraya \\
\hline$P L U V A$ & $F$ & + & - & & $\$ \$$ & $A$ & DF & Schenk \\
\hline$Q P D A$ & $F$ & + & - & $E$ & $F$ & $A$ & $M$ & Hill/Madsen \\
\hline QUANTSS & $F$ & + & - & $S$ & $F$ & $A$ & $M$ & Hubbard/Snyder \\
\hline$R I M P A C$ & GWB & - & + & $\mathrm{E}$ & $\$ \$$ & A & $\mathbf{M}$ & Davis \\
\hline SIROQUANT & $F$ & + &.+ & $E$ & C & $A$ & $M$ & Taylor \\
\hline
\end{tabular}

Quantitative phase analysis by X-ray powder diffraction is one of the few techniques which is truly phase sensitive rather than element sensitive. The first applications followed the development of the theory by Alexander \& Klug (1948). Although the technique was applied effectively to some special problems, the data collection was laborious and limited the general application of the method. When the APD became the data collector, the data were easier to analyse and the technique saw enhanced use in the 1980's which has continued to the present time.

There are basically three ways of doing quantitative analysis at the present time. One technique uses integrated intensities (areas) of individual peaks for each of the phases in the mixture if peaks are resolvable and clusters of peaks when they are not. With the raw data in digitized form, it is easy to integrate the desired diffraction ranges for the calculation. QUANT85, PC/PEAKS, microQUANT and $R I M P A C$ use this approach. GMQUANT and $A R C O Q U A N T$ use the full diffraction trace with a reference database of digitized traces of reference patterns. The other programs are Rietveld programs modified to emphasize the quantification of phases in a mixture by adjusting the pattern scale factors for absorption effects. All these approaches are effective if the sample-preparation problems can be overcome.

\section{Structure determination (powder)}

$\begin{array}{lcccccccl}\text { Lrogram } & \text { Language } & \mathrm{MF} & \mathrm{PC} & \text { Form } & \text { Cost } & \text { Support } & \text { Documentation } & \text { Source } \\ \text { SIRPOW90 } & F & + & + & & & & & \text { Cascarano } \\ \text { STRUMO } & F & + & - & F & F & A & \text { DF } & \text { Brown, I. D. }\end{array}$

There has long been a reluctance to claim that structures can be solved based on powder data alone, but recent successes have proved that the time to exploit the technique is now. Several programs, mentioned under full-pattern fitting, have been designed to resolve intensities so that they can be used in single-crystal calculations, but recent efforts have been to design programs that work directly on the powder information as a package. Two such programs have been identified so far, and they are listed separately under a different heading. 
Structure display

\begin{tabular}{|c|c|c|c|c|c|c|c|c|}
\hline \multirow[b]{2}{*}{ Program } & \multicolumn{4}{|c|}{ Compuler } & \multirow[b]{2}{*}{ Cost } & \multirow[b]{2}{*}{ Support } & \multirow[b]{2}{*}{ Documentation } & \multirow[b]{2}{*}{ Source } \\
\hline & Language & $\mathrm{MF}$ & $\mathrm{PC}$ & Form & & & & \\
\hline ATOMS & $B$ & - & + & $E$ & $C$ & $A$ & $M$ & SHAPE/PEB \\
\hline$B \& S$ & $B$ & - & + & $E$ & $C$ & $A$ & $M$ & SHAPE \\
\hline CENG. ORTEP & $F$ & + & -- & $S$ & $\$$ & $A$ & DF & ILL \\
\hline CRYES & GWB & - & + & $E$ & $C$ & $A$ & $M$ & Vila(2)/Vegas \\
\hline CRYST & $F$ & FAC & $\mathrm{OM}$ & $S$ & $\$$ & $N$ & $M$ & Sakurai \\
\hline$F I G A T O$ & $F$ & + & - & $S$ & $F$ & & DF & Langlet/PEB \\
\hline INORGEGA & & - & + & $S$ & $F$ & $A$ & DF & Jansen/PEB \\
\hline$M O D E L / N A M O D$ & $F$ & + & - & $S$ & $\$ \$$ & $A$ & DF & Smith, D. \\
\hline$M O L D R A W$ & QB & - & + & $E$ & $\$$ & $A$ & DF & Ugliengo \\
\hline MOLPLOT & $F$ & - & + & $S$ & $F$ & $A$ & $R$ & Radhakrishnan \\
\hline NAMOD & $F$ & + & + & $s$ & $F$ & $N$ & $R$ & Beppu (PDB)/PEB \\
\hline ORTEP (Updated PEB) & $F$ & + & - & $S$ & $F$ & $N$ & $M$ & Johnson, C. $/$ PEB \\
\hline PLOTMOL & $F$ & + & + & $S$ & $\$$ & $A$ & DF & Gabe \\
\hline PLOTMD & $F$ & + & - & $S$ & $F$ & $A$ & DF & Luo \\
\hline PLORTEP & $F$ & + & - & & & & $R$ & Bandel/Sussman \\
\hline PLATON & $F$ & + & + & $S$ & $\$ \$$ & $A$ & $M$ & Spek/PEB \\
\hline PLUTO (Updated PEB) & $F$ & + & - & & $\$ \$$ & $A$ & $M$ & Motherwell/PEB \\
\hline PLUVA & $F$ & + & - & $S$ & $\$ \$$ & $A$ & DF & Schenk \\
\hline PRETEP & $F$ & + & + & $S$ & $F$ & $A$ & DF & Izumi/PEB \\
\hline$Q S H A P E$ & $B$ & - & + & $E$ & $C$ & $A$ & $M$ & SHAPE \\
\hline SCHAKAL-88B & $F$ & + & + & $S$ & $L$ & $A$ & DF & Keller \\
\hline$S C H A K A L-88 \mathrm{~B}: V 16$ & $F$ & - & + & $E$ & $L$ & $A$ & $M$ & Keller \\
\hline$S D P$ & $F, C$ & + & + & $E$ & $C$ & $A$ & DF & Frenz \\
\hline$S H A P E$ & $B$ & - & + & $E$ & $C$ & $A$ & $M$ & SHAPE \\
\hline STRUPLO & $F$ & + & - & $S$ & $F$ & $A$ & $M$ & Fischer \\
\hline$S T R U P L O / P C$ & $F$ & - & + & $S$ & $\$$ & $A$ & $M$ & le Lirzin \\
\hline
\end{tabular}

Powder diffractionists may feel that structure graphics are not in the realm of powder diffraction, but with the increased activity in solving crystal structures from powder data that is not true. Also, there is considerable research on the effects of atom substitutions in structures and the ability to display easily the structure image on a screen often helps one to see what is happening. With the availability of the several structure databases which contain structure descriptions, a coupled display program results in a very powerful tool in the laboratory.
The problem with structure graphics is the dependence of the programs on the hardware. There are many sophisticated graphics systems available today and some of the programs have taken advantage of them. Most of the programs in the list were initially designed for the pen-driven plotter, some of which have been upgraded to newer plotters. When one of the programs is requested, it is necessary that the requestor obtain information on the graphics requirements.

\section{Small-angle scattering}

$\begin{array}{lcccccccl}\text { Program } & \text { Language } & \text { MF } & \text { PC } & \text { Form } & \text { Cost } & \text { Support } & \text { Documentation } & \text { Source } \\ \text { FFSAXS } & F & + & - & S & F & A & \text { DF } & \text { Vonk/PEB } \\ \text { ITP-81 } & F & + & - & S & F & A & \text { DF } & \text { Glatter/PEB } \\ \text { LIPFIT } & F & + & - & S & F & A & \text { DF } & \text { Gooris/PEB } \\ \text { RAD } & F & - & + & S & F & A & \text { DF } & \text { Petkov } \\ \text { SAXSFIT } & F & + & - & S & F & A & \text { DF } & \text { Gooris/PEB } \\ \text { SIMUL/SCAT } & F & + & - & S & F & A & \text { DF } & \text { Hansen/PEB } \\ \text { STACKS } & F & + & - & S & F & A & \text { DF } & \text { Gooris/PEB } \\ \text { TRACON } & F & + & - & S & F & A & \text { DF } & \text { Gooris/PEB }\end{array}$

Although small-angle scattering is not technically powder diffraction, powder samples may be analysed and powder diffractometers may be modified to obtain the experimental data. There was no effort made in this project specifically to cover the field of small-angle scattering. The list presented here has been obtained through the courtesy of Drs Ing. S. Gorter of the Dutch Association of Crystallographers, and it is included here for those who may be interested. No comments will be made on these programs because the publication authors lack experience in their use. 
Miscellaneous programs

\begin{tabular}{lcccccccl} 
Program & \multicolumn{9}{c}{ Computer } & & & \\
LAMMAG & $F$ & + & - & $S$ & $F$ & $A$ & DF & Gerloch/PEB \\
DIMFIT & $F$ & + & - & $S$ & $F$ & $A$ & DF & Gorter/PEB \\
ELMIC & $F$ & + & - & $S$ & $F$ & $A$ & DF & van Dijck/PEB \\
ESR & $F$ & + & - & $S$ & $F$ & $A$ & DF & Ammeter/PEB \\
FPLOT & $F$ & + & - & $S$ & $F$ & $A$ & DF & Rutten/PEB \\
HKL-XTAL & $F$ & + & - & EP & FL & $A$ & DF & Jansen/PEB \\
HOLE & $F$ & + & - & $S$ & $F$ & $A$ & DF & de Kok/PEB \\
LABSCO & $F$ & + & - & $S$ & $F$ & $A$ & DF & Driessen/PEB \\
MADELUNG & $F$ & + & - & $S$ & $F$ & $A$ & DF & Gorter/PEB \\
MTH-RD & $F, P$ & + & - & $S$ & $F$ & $A$ & DF & Jansen/PEB \\
MU & GFA & + & - & S & F & A & DF & de Graaf/PEB \\
ONE-TO-POWDER & $F$ & + & - & EP & FL & $A$ & DF & Jansen/PEB \\
& & & & & & & &
\end{tabular}

\section{Other programs}

been accomplished. If the program was commercial and purchased outright, then the requirement for referencing the work becomes unnecessary, but it would still be a service to readers in the same way that equipment and samples are recognized.

Another problem with programs that is appearing often is the second-author modification of routines which are then distributed independently of the primary program. Sometimes the second program is being marketed for financial gain without any agreement with or remuneration to the primaryprogram author. This practice is most common with, but not limited to, PC programs patterned after main-frame versions. The basic problem lies in the interpretation of copyrights but there are ethical aspects as well. If the requestor remembers there is a requirement to recognize the previous work that has lead to the new advances, whether they are new results or a modified program, this problem will be minimized.

\section{Future revisions of this list}

available from the program author(s) or as part of one of the analytical packages of programs. The program tables indicate the probable level of costs involved and the program author or program source. More detail on the program source is provided in the following address list or in the references. The program-author list is indexed by the name of the program author or company responsible for the program. If there is no entry in the source list, there will be an entry in the references. When asking for copies of programs, requestors should expect to supply media especially for free programs.

When requesting programs, the requestor should recognize the tremendous amount of time and talent required to prepare good programs. This effort must be recognized. If the program is delivered at no cost or for minimal copying and media fees, the program must be referenced in any publication that results from calculations made using the program. Usually, without the program, the research would not have

The maintenance of this list of programs will depend on its value to the powder diffraction community which will be measured by the comments, criticisms, suggestions and new program information it generates. Users should direct all remarks to the publication authors, not to the IUCr office or to the Commission on Powder Diffraction. Corrections are welcome and all new program information will be filed for the next update.

Program authors desiring to have a program listed should follow the format in the questionnaire in the Appendix. All of the questions are essential and the more information supplied the better. When this list was first conceived, one plan was to have a short abstract on each program. Unfortunately, the response to requests for information was too variable to retain this goal. About $25 \%$ of the program authors did not return the form. Before the next list is compiled, each program author will be asked once 
again to bring the data up to date and to prepare a program abstract.

There are certainly many laboratories that have collections of programs for powder diffraction applications that have not been identified in this project. Some researchers do not think they have any programs of outside interest. Some prefer not to have to polish for distribution a program they wrote for personal use and they do not want to have to take the time to prepare instructions on its use. Others do not want to have to answer questions on how to use their programs. Still others consider their version too similar to distributed programs to be of interest to others. Whatever the reason, the result is unfortunate in that the program does not achieve its full potential through input from other users. All these programs should be included in this list.

Another problem is geographic in nature. Researchers in countries other than the industrial nations consider their programs of little interest to others. Commonly, the programs are written for computers of limited availability. Actually, these programs are of considerable value in this list because they allow users who have similar computers to locate colleagues with whom they can exchange routines. Program authors in this category are encouraged to submit program information.

The publication authors thank the many program authors who responded to the requests for information. Special thanks are extended to Professor Gerald G. Johnson Jr and Dr Susan Q. Hoyle who read the manuscript several times and to Professor R. A. Young and the other members of the Commission on Powder Diffraction who have supplied considerable information for this report, reviewed the manuscript and continue to encourage us to continue the project.

\section{Sources for programs}

Allmann

R. Allmann

Fachbereich Geowissenschaften

Philips Universität

Lahnberge

D-3550 Marburg

Germany

Ammeter

J. H. Ammeter

(see PEB)

Antoniadis

A. Antoniadis

Université de St Etienne

Department of Mathematics

23 Rue du Docteur Paul Michelon

42100 St Etienne CEDEX

France
Appleman

D. E. Appleman

Department of Mineral Science

Smithsonian Institution

NHB 119, Room E-408A

Washington, DC 20560

United States

Bärlocher

C. Bärlocher

Institut für Kristallographie und Petrographie

ETH-Zentrum

CH-8092 Zurich

Switzerland

Bartell

L. S. Bartell

Department of Chemistry

University of Michigan

Ann Arbor, MI 48109

United States

Benham

M. J. Benham

School of Physics and Space Research

University of Birmingham

Birmingham B15 2TT

Great Britain

Benoit

Paul Benoit

Department of Geology

31 Williams Hall

Lehigh University

Bethlehem, PA 18015

United States

Beppu

Yoshitaka Beppu

Laboratory of Theoretical Biophysics

Department of Physics

Nagoya University

Nagoya 464

Japan

Bergerhoff

G. Bergerhoff

Institut für Anorganische Chemie

Universität Bonn

Gerhard Domagkstrasse 1

D-5300 Bonn 1

Germany

Bish

David L. Bish

ESS-1, Geology/Geochemistry

MS D469

Los Alamos National Laboratory

Los Alamos, NM 87545

United States 
Blanchard

Frank N. Blanchard

Department of Geology

University of Florida

Gainesville, FL 32611

United States

Bosman

W. Bosman

Katholieke Universiteit Nijmegen

Laboratorium voor Kristallografie

Toernooiveld

NL-6525 ED Nijmegen

The Netherlands

Bourniquel

B. Bourniquel

LAMM, IUT, BP 420

44606 St Nazarine CEDEX

France

Brown, A.

Allan Brown

Marmorvogen 2

S-61144 Nykoping

Sweden

Brown, I. D.

I. D. Brown

Department of Chemistry

McMaster University

Hamilton, Ontario L8S 4M I

Canada

Burla

M. C. Burla

Dipartimento di Scienze della Terra Università Perugia

I-06100 Perugia

Italy

Burnham

Charles W. Burnham

Hoffman Laboratory

Harvard University

20 Oxford Street

Cambridge, MA 02138

United States

Burova

E. M. Burova

Moscow State University

Computer Department

Leninskiye Gory

Moscow 117234

USSR

Byrom

P. G. Byrom

(see Lucas)
Caillat

J. C. Caillat

Department of Chemistry

University of Michigan

Ann Arbor, MI 48109

United States

Cambridge

Cambridge Crystallographic Data Centre

University Chemical Laboratory

Lensfield Road

Cambridge CB2 IEW

Great Britain

Canfield

Dennis V. Canfield

University of Southern Mississippi

Department of Polymer Science

Hattiesburg, MS 39406-0076

United States

Carr

Martin J. Carr

Sandia National Laboratory

Division 1822

Albuquerque, NM 87185

United States

Cascarano

G. Cascarano

(see Burla)

Cherner

Yakov E. Cherner

Institute of Physics

194 Stachko Ave

344104 Rostov-on-Don

USSR

Clayton

William Rex Clayton

Miller Brewing Company

3939 West Highland Boulevard

Milwaukee, WI 53208

United States

Clearfield

Abraham Clearfield

Department of Chemistry

Texas A\&M University

College Station, TX 77843

United States

Cohen

Jerome B. Cohen

Technical Institute

Northwestern University

Evanston, IL 60201

United States 
Cooper

M. J. Cooper

Materials Physics Section

AERE Harwell

Oxfordshire OXI1 ORA

Great Britain

Cox

D. E. Cox

Physics Department

Brookhaven National Laboratory

Upton, NY 11973

United States

Davis

Briant L. Davis

Institute for Atmospheric Research

South Dakota School of Mines

Rapid City, SD 57701-3995

United States

Dinnebier

R. E. Dinnebier

Mineralogisch-Petrographisches Institut

Universität Heidelberg

Im Neuenheimer Feld 236

D-6900 Heidelberg

Germany

van Dijck

D. van Dijck

Laboratorium voor Hoogspannings Electronen Microscopie

RUCA

Groenenforgerlaan 27

Antwerpen

Belgium

DL

S. S. Hasnain

SERC Daresbury Laboratory

Warrington, Cheshire WA4 4AD

Great Britain

Dowty

Eric Dowty

196 Beechwood Avenue

Bogota, NJ 07603

United States

Driessen

W. L. Driessen

Gorlaeus Laboratories

Einsteinweg 5

NL-2333 CC Leiden

The Netherlands

Enzo

S. Enzo

(see Polizzi)
Eriksson

L. Eriksson

KEJ Instruments

Erikslundsvagen 236

S-183 47 Taby

Sweden

Espinat

D. Espinat

Institut Français du Pétrole

1-4 Avenue de Bois Préau

F-92506 Rueil Malmaison CEDEX

Villeurbanne

France

Eysel

Walter Eyse]

Mineralogisch-Petrographisches Institut

Universität Heidelburg

Im Neuenheimer Feld 236

D-6900 Heidelburg

Germany

Fiala

Jaroslov Fiala

Department of Metallurgy

Central Research Institut Škoda

Tylova 46

31600 Plzeň

CSSR

Fischer

Reinhard X Fischer

Mineralogisches Institut

Universität Würzburg

D-8700 Würzburg

Germany

FIZ

Fachsinformationzentrum für Energie Physik Mathematik

D-7514 Eggenstein-Leopoldshafen 2

Germany

Foris

C. M. Foris

Central Research and Development

E. I. DuPont de Nemours \& Co.

Experimental Station, Bldg 356

Wilmington, DE 19898

United States

Frenz

B. A. Frenz

B. A. Frenz and Associates, Inc.

900 E. Harvey Road, Suite 16

College Station, TX 77840

United States 
Gabe

Eric J. Gabe

Chemistry Division

National Research Council

Ottawa, Ontario K1J 8L9

Canada

Garbauskas

Mary F. Garbauskas

General Electric Company

Corporate Research and Development

PO Box 8, K-1 2C35

Schenectady, NY 12301

United States

Garvey

Roy G. Garvey

Department of Chemistry

North Dakota State University

Fargo, ND 58105-5516

United States

Gerloch

M. Gerloch

(see PEB)

Gerward

L. Gerward

Laboratory of Applied Physics III

Building 307

Technical University of Denmark

DK-2800 Lyngby

Denmark

Gilkes

R. J. Gilkes

(see Singh)

Glatter

O. Glatter

(see PEB)

Goehner

Raymond A. Goehner

Sandia National Laboratory

Albuquerque, NM 67185

United States

Gooris

G. S. Gooris

(see PEB)

\section{Gorter}

Syb Gorter

Gorlaeus Laboratories

Einsteinweg 5

NL-2333 CC Leiden

The Netherlands

de Graaf

R. A. G. de Graaf

(see PEB)
Hall

S. R. Hall

Crystallography Centre

University of Western Australia

Nedlands, 6009 Western Australia

Australia

Hansen

Steen Hansen

Department of Physics

Royal Veterinary and Agricultural University

Thorvaldsenvej 40

DK-1871 Fredriksberg C

Denmark

Harlow

Richard L. Harlow

Central Research and Development

E. I. DuPont de Nemours \& Co.

E228/316 D

Wilmington, DE 19898

United States

Helmholdt

R. Helmholdt

Energy Centrum Nederland

Physics Department, PO Box 1

NL-1755 ZG Petten

The Netherlands

Hewat

Alan Hewat

(see ILL)

Hill

Roderick J. Hill

Division of Mineral Chemistry

CSIRO, PO Box 124

Port Melbourne, Victoria 3207

Australia

Himes

V. L. Himes

(see Mighell)

Hovestreydt

Eric R. Hovestreydt

Institut für Kristallographie

Universität Karlsruhe

D-7500 Karlsruhe

Germany

Howard, C.

C. Howard

(see Hill)

Howard, S.

Scott A. Howard

Department of Ceramic Engineering

University of Missouri-Rolla

Rolla, MO 65401

United States 
Hubbard

Camden R. Hubbard

Oak Ridge National Laboratory, PO Box 2008

Oak Ridge, TN 37831

United States

ICDD

International Centre for Diffraction Data

1601 Park Lane

Swarthmore, PA 19081

United States

ILL

Alan Hewat

Institut Laue-Langevin

Avenue des Martyrs, BP $156 \mathrm{X}$

F-38042 Grenoble CEDEX

France

IPNS

(see Mueller)

INEL

J. P. Duchemin

INEL, Avenue de Scandinavie

$Z$ A de Courtaboeuf

91953 Les Ulis CEDEX

France

Izumi

F. Izumi

National Institute for Research in Inorganic Materials

1-1 Namiki Tsukuba-shi

Ibaraki 305

Japan

Jansen

J. Jansen

University of Amsterdam

Laboratorium voor Kristallografie

Nieuwe Achtergracht 166

NL-1018 WV Amsterdam

The Netherlands

Jenkins

Ron Jenkins

JCPDS-ICDD, 1601 Park Lane

Swarthmore, PA 19081

United States

Johnson, C.

Carroll K. Johnson

Oak Ridge National Laboratory, PO Box 2008

Oak Ridge, TN 37831

United States

Johnson, $\mathrm{G}$.

Gerald G. Johnson Jr

164 Materials Research Laboratory

The Pennsylvania State University

University Park, PA 16802

United States
Johnson, Q.

Quintin C. Johnson

Materials Data, Inc., PO Box 791

Livermore, CA 94550

United States

Jones

Rolland C. Jones

Department of Agronomy

University of Hawaii

1910 East West Road

Honolulu, HI 96822

United States

Kallend

John Kallend

Illinois Institute of Technology

Chicago, IL

United States

Kaplan

W. D. Kaplan

(see Kimmel)

Kawahara

A. Kawahara

Faculty of Science

Okayama University

3-1-1 Tsushimanaka

Okayama 700

Japan

Keller

Egbert Keller

Kristallographisches Institut der Universität

Hebelstrasse 25

D-7800 Freiburg

Germany

Kennard

Olga Kennard

University Chemical Laboratory

Lensfield Road

Cambridge CB2 1EW

Great Britain

Kimmel

Giora Kimmel

Nuclear Research Center-Negev

PO Box 9001

Beer-Sheva 84190

Israel

Kogan

Vladimir Kogan

Rostov-on-Don State University

5 Zorge Str.

344104 Rostov-on-Don

USSR 
Kohlbeck

F. Kohlbeck

TU Wein, Abteilung Geophysik

Gasshausstrasse 27-29

A-1040 Wein

Austria

de Kok

A. de Kok

(see PEB)

Langford

J. I. Langford

School of Physics and Space Research

University of Birmingham

Birmingham B15 2TT

Great Britain

Langlet

G. Langlet

(see PEB)

Larson

Allen C. Larson

Physics Division P-8, MS-H805

Los Alamos National Laboratory

Los Alamos, NM 87545

United States

Lawton

Stephen L. Lawton

Mobil Research and Development Corp.

Research Department

Billingsport Road

Paulsboro, NJ 08096

United States

Lengauer

C. L. Lengauer

Universität Salzburg

Mineralogisches Institut

Hellbrunnerstrasse 34

A-5020 Salzburg

Austria

Lin

Lin Tian-Hui

Shanghai Iron and Steel Research Institute

105 Tai-Ho Road

Wu Sung, Shanghai

People's Republic of China

le Lirzin

A. le Lirzin

Laboratoire de Chimie du Solide du CNRS

351 Cours de la Liberation

33405 Talence CEDEX

France
Louër

Daniel Louër

Laboratoire de Cristallochimie

Université de Rennes

Avenue du Général Leclerc

35042 Rennes CEDEX

France

Lucas

B. W. Lucas

Department of Physics

University of Queensland

St Lucia, Brisbane

Queensland 4067

Australia

Luo

J. Luo

H. L. Ammon

Department of Chemistry and Biochemistry

University of Maryland

College Park, MD 20742

United States

Marquart

Fein-Marquart Associates, Inc.

7215 York Road

Baltimore, MD 21212

United States

Mallory

Chester L. Mallory

Prometix Corporation

3255 Scott Boulevard, Building 2

Santa Clara, CA 95054

United States

Melzer

Rolf Melzer

Institut für Mineralogie und Kristallographie

Technische Universität Berlin, Sekr BH 1

Ernst Reuten Platz 1

D-1000 Berlin 12

Germany

Mighell

Alan D. Mighell

National Institute of Standards and Technology

A209, MATLS

Gaithersburg, MD 20899

United States

Motherwell

William D. S. Motherwell

Automation Office

Cambridge University Library, West Road

Cambridge CB3 9DR

Great Britain 
Mueller

Melvin H. Mueller

IPNS Building 360

Argonne National Laboratory

9700 Cass Avenue

Argonne, IL 60439

United States

Mugnoli

A. Mugnoli

Istituto di Chimica Fisica

Università di Genova

Corso Europa

I-16132 Genova

Italy

Nickel

Ernest H. Nickel

CSIRO, Division of Mineral Products

Wembley PO

Western Australia 6014

Australia

Novak

G. A. Novak

Department of Geology

California State University at Los Angeles

Los Angeles, CA 90032

United States

NRCC

Gordon H. Wood

CISTI

National Research Council of Canada

Ottawa, Ontario K1A 0S2

Canada

Nurmela

S. Nurmela

(see Suortti)

O'Connor

Brian H. O'Connor

WAITEC Consulting Services

Kent Street, Bentley

Western Australia 6102

Australia

Okamoto

F. Okamoto

(see Kawahara)

Paszkowicz

Wojciech Paszkowicz

Sinus S/C, UL

Raclawicka 33 M.40

02-601 Warsaw

Poland
Pawley

G. Stuart Pawley

Department of Physics

University of Edinburgh

Mayfield Road

Edinburgh EH9 3JZ

Great Britain

PDB

Protein Data Bank

F. C. Bernstein

Department of Chemistry

Brookhaven National Laboratory

Upton, NY 11973

United States

PEB

Program Exchange Bank for the Dutch Association of Crystallographers

Syb Gorter

Gorlaeus Laboratories

State University of Leiden

Einsteinweg 5

NL-2333 CC Leiden

The Netherlands

Polizzi

S. Polizzi

Dipartimento di Chimica Fisica

Università di Venezia

I-30123 Venezia

Italy

Prewitt

Charles T. Prewitt

Geophysical Laboratory

2801 Upton Street

Washington, DC 20008-3898

United States

Prince

Edward Prince

Reactor Radiation Division

National Institute of Standards and Technology

Bldg 235-A 106

Gaithersburg, MD 20899

United States

Radhakrishnan

R. Radhakrishnan

Department of Crystallography and Biochemistry

University of Madras

Guindy Campus

Madras 600025

India

RAL

Rutherford-Appleton Laboratory

Neutron Division

Chilton, Didcot

Oxon OX11 0QX

Great Britain 
Reynolds

Robert C. Reynolds

Department of Earth Sciences

Dartmouth College

Hanover, NH 03755

United States

Rodgers

J. D. Rodgers

(see NRCC)

\section{Rodriguez-Carvajal}

J. Rodriguez-Carvajal

Institut Laue-Langevin

Avenue des Martyrs, BP 156X

F-38042 Grenoble, CEDEX

France

Rogers

K. D. Rogers

Applied Physics \& Electro-Optics Group

Royal Military College of Science

Shrivenham, Swindon

Wiltshire SN6 8LA

Great Britain

Roof

B. R. Roof

2700 Vista Grance NW No. 102

Albuquerque. NM 87120

United States

Rossell

Henry J. Rossell

Division of Materials Science

CSIRO, Normanby Road

Clayton, Victoria 3168

Australia

Rudolf

P. R. Rudolf

Analytical Sciences, 1897 Building

Dow Chemical USA

Midland, MI 48667

United States

Russ

John C. Russ

School of Engineering

North Carolina State University

PO Box 5995

Raleigh, NC 27650

United States

Rutten

Els Rutten-Keulemans

(see PEB)
Sakurai

K. Kobayashi

c/o T. Sakurai

Faculty of Education

Shinshu University, Nishinagano

Nagano 380

Japan

Schenk

H. Schenk

University of Amsterdam

Laboratorium voor Kristallografie

Nieuwe Achtergracht 166

NL-1018 VW Amsterdam

The Netherlands

Schneider

Julius Schneider

Institut für Kristallographie und Mineralogie

Universität München

Theresienstrasse 41

D-8000 München 2

Germany

Scott

Henry G. Scott

CSIRO, Division of Materials Science

Normanby Road

Clayton, Victoria 3168

Australia

Setten

A. Setten

Laboratoire d'Etudes Physicochimiques

UER de Sciences Fondamentales et Appliqué

F-45045 Orléans CEDEX

France

SHAPE

(see Dowty)

Sheldrick

George M. Sheldrick

Institut für Anorganische Chemie

Universität, Tammannstrasse 4

D-3400 Göttingen

Germany

Siemens

Siemens Europa SA

Charleroisesteenweg 116

B-1060 Bruxelles

Belgium

Sietronics

Rod Clapp

Sietronics Pty Ltd

PO Box 521, Fyshwick

Australian Capital Territory 2609

Australia 
Singh

Balbir Singh

Soil Science and Plant Nutrition

University of Western Australia

Nedlands, WA 6009

Australia

Smith, D.

Deane K. Smith

Department of Geosciences

239 Deike Building

The Pennsylvania State University

University Park, PA 16802

United States

Smith, K

Kingsley L. Smith

309 N. Rosa Road

Madison, WI 53705

United States

Snyder

Robert L. Snyder

College of Ceramics

Alfred University

Alfred, NY 14802-1296

United States

Socabim

Socabim

Julian Nusinovici

9 Bis Villa du Bel-Air

Paris 75012

France

Sonneveld

Eduard J. Sonneveld

Technische Physische Dienst TNO-TU

Stieltjesweg 1, PO Box 155

2600 AD Delft

The Netherlands

Spek

Anthony L. Spek

Lab. voor Kristal- en Structuurchemie

Universitet Utrecht

Padualaan 8, PO Box 80050

$3584 \mathrm{CH}$ Utrecht

The Netherlands

Stewart

James M. Stewart

Department of Chemistry

University of Maryland

College Park, MD 20742

United States
Suortti

Pekka Suortti

Department of Physics

University of Helinski

Siltavuorenpenger $20 \mathrm{D}$

SF-00170 Helsinki 17

Finland

Taupin

Daniel Taupin

Laboratoire de Physique des Solides Associé au CNRS

Bâtiment 510, Centre Universitaire

F-91405 Orsay

France

Taylor

J. C. Taylor

Fuel Technology Division CSIRO

Lucas Heights Research Laboratories

Private Mail Bag 7

Menai, NSW 2234

Australia

TEXSAN

TEXSAN

3200A Research Forest Drive

The Woodlands, TX 77381

United States

Toby

Brian H. Toby

Department of Materials Science

University of Pennsylvania

Philadelphia, PA 19104-6272

United States

Toraya

Hideo Toraya

Ceramic Engineering Research Center

Nagoya Institute of Technology

Asahigaoka, Tajimi 507

Japan

Tsytsenko

Anton Tsytsenko

191023 Leningrad

Apraksin per, 1

USSR

Ugliengo

Pierre Ugliengo

Gruppo di Chimica Fisica

Università degli Studi di Torino

Via P. Giuria 7

I-10125 Torino

Italy 
POWDER DIFFRACTION PROGRAM INFORMATION

Vegas

A. Vegas

Instituto de Quimica Inorganica

CSIC, Serrano 113

28006 Madrid

Spain

Vila(1)

A. Vila

Instituto de Ciencia de Materiales

CSIC, Serrano 113

28003 Madrid

Spain

Vila(2)

SciSoft

Attn: Mr. Arias

c/ Providencia 27

E-08800 Vilanova i La Geltru

Barcelona

Spain

Visser

J. W. Visser

(see Sonneveld)

Von Dreele

R. B. Von Dreele

Los Alamos National Laboratory

Neutron Scattering Center

Physics Division

Los Alamos, NM 87545

United States

Vonk

C. G. Vonk

Beatrixlaan 12

6165 CX Geleen

The Netherlands

Wassermann

A. Wassermann

Kaufbeurerstrasse 4

Postfach 2631

D-8960 Kempten

Germany

Watkin

David J. Watkin

Chemical Crystallography Laboratory

University of Oxford

9 Parks Road

Oxford OX1 3PD

Great Britain

Wenk

H. R. Wenk

Department of Geology

University of California

Berkeley, CA

United States
Watson

David G. Watson

(see Kennard)

Werner

Per-Erik Werner

Arrhenius Laboratory

University of Stockholm

S-106 91 Stockholm

Sweden

White

P. S. White

Chemistry Department

University of New Brunswick Fredericton

New Brunswick E3B 5A3

Canada

Will

Georg Will

Mineralogisches Institut der Universität

Poppelsdorfer Schloss,

D-5300 Bonn

Germany

Wims

Andrew M. Wims

Research Center

General Motors Technical Center

30500 Mound Road

Warren, MI 48090

United States

Wood

Gordon H. Wood

(see NRCC)

$\mathrm{Wu}$

E. Wu

School of Physical Sciences

Flinders University of South Australia

Bedford Park, SA 5042

Australia

Young

R. A. Young

School of Physics

Georgia Institute of Technology

Atlanta, GA 30332

United States

Yerkess

J. Yerkess

Computer Centre

University of Bradford, Bradford

West Yorkshire BD7 1DP

Great Britain

Zhang

S.-Z. Zhang

(see Hubbard) 
Zhou

R. S. Zhou

(see Snyder)

\section{References}

Abad-Zapatero, C. \& O'Donnell, T. J. (1987). TABLES, a program to display space-group symmetry information in three dimensions. J. Appl. Cryst. 20, 532-535.

Alexander, L. E. \& Klug, H. P. (1948). Basic aspects of $X$-ray absorption in quantitative diffraction analysis of powder mixtures. Anal. Chem. 20, 886 889.

Allen, F. H., Bergerhoff, G. \& Sievers, R. (1987). Editors. Crystallographic Databases. International Union of Crystallography, Chester, England.

AllmanN, R. (1990). A cheap automation of X-ray powder diffractometers. IUCr Symposium on Powder Diffraction, Toulouse, France. Abstracts, p. 281.

Antoniodis, A., Berruyer, J. \& Filhol, A. (1990). Profile fitting with help of a maximum-likelihood method. IUCr Symposium on Powder Diffraction. Toulouse, France. Abstracts, p. 85.

Appleman, D. E. \& Evans, H. T. JR (1973). US Geological Survey Computer Contribution 20. US National Technical Information Service Document PB2-16188.

Armstrong, E. E. \& Cameron, D. G. (1989). The use of Fourier self-deconvolution to resolve overlapping $X$-ray povider diffraction peaks. Powder Diffr. 4, 144 151.

Azaroff, L. V. \& Buerger, M. J. (1958). The Powder Method in X-ray Crystallography. New York: McGrawHill.

Bandel, G. \& Sussman, J. L. (1983). PlorTeP: a computer program to translate PLUTO instructions into those of ORTEP. J. Appl. Cryst. 16, 650-651.

BARKer, T. V. (1922). Graphical and Tabular Methods in Crystallography as a Foundation of a New System of Practice. London: T. Murby.

Bärlocher, Ch., Hepp, A. \& MeIer, W. M. (1977). $D L S-76$. A program for the Simulation of Crystal Structures by Geometric Refinement. Institute of Crystallography and Petrology, ETH, Zürich, Switzerland.

Bartel, L. S. \& Caillat, J. C. (1987). A method for analyzing powder patterns of phases of low symmetry. $J$. Appl. Cryst. 20, 461-466.

BeLOIT, P. H. (1987). Adaptation to microcomputer of the Appleman-Evans program for indexing and least-squares refinement of powder diffraction data for unit-cell dimensions. Am. Mineral. 72, 1018-1019.

Benedetti, A., Fagherazzi, G., Enzo, S. \& BattagliaRIN, M. (1988). A profile-fitting procedure for analysis of broadened X-ray diffraction peaks. II. Applications and discussion of the methodology. J. Appl. Cryst. 21, 543-549.

Benham, M. J. \& Ross, D. K. (1986). ATALANTA: a multicomponent pulsed-neutron diffraction analysis code. Inst. Phys. Conf. Ser. No. 81, ch. 1.

BERGERHOFF, G. \& BROWN, I. D. (1987). Inorganic Crystal Structure Database. In Crystallographic Databases, edited by F. H. Allen, G. Bergerhoff \& R. Sievers, pp. 77-95. International Union of Crystallography, Chester, England.
Bfrti, G., Di Guglielmo, G. \& Marzoni Fecia Di Cossato, Y. (1990). The interpretation of powder diffraction patterns by numerical and computer-graphics systems. J. Appl. Cryst. 23, 6-10.

BisH, D. L. \& Howard, S. A. (1988). Quantitative phase analysis using the Rietveld method. J. Appl. Cryst. 21, $86-91$.

Bonetto, R. D., Viturro, H. R. \& Alvarez, A. G. (1990). XTL-SIZE: a computer program for crystal-sizedistribution calculation from $X$-ray diffraction line broadening. J. Appl. Cryst. 23, 136-137.

Bourniquel, B., Guillen, R. \& Feron, J. L. (1990). Texture analysis. Applications of the profile-fitting method to data collected with a PSD. IUCr Symposium on Powder Diffraction, Toulouse, France. Abstracts, p. 65.

Brown, B. E. \& BAILEY, S. W. (1962). Chlorite polytypism: I. Regular and semi-random one-layer structures. Am. Mineral. 47, 819-850.

Burla, M. C., Camalli, M., Cascarano, G., Giacovazzo, C., Polidori, G., Spagna, R. \& Viterbo, D. (1989). SIR88 - a direct-methods program for the automatic solution of crystal structures. J. Appl. Cryst. 22, 389-393.

Burnham, C. W. (1965). Refinement of lattice parameters using systematic correction terms. Carnegie Inst. Washington Yearb. 64, 200-202.

Byrom, P. G., Hoffmann, S. E. \& Lucas, B. W. (1989). MORGUE, a neutron powder diffraction profile refinement program with control-file facility to include structural and rigid-body thermal-motion constraints. $J$. Appl. Cryst. 22, 629-633.

Byrom, P. G. \& Lucas, B. W. (1991). POWABS: a computer program for the automatic determination of reflection conditions in powder diffraction patterns. $J$. Appl. Cryst. 24, 70-72.

CANUT-AMOROS, M. (1970). STLPLT: Calcomp plot of crystallographic projections of Laue photographs. Comput. Phys. Commun. 1, 293-305.

Carr, M. J., Chambers, W. F. \& Melgaard, D. (1986). A search/match procedure for electron diffraction data based on pattern matching with binary bit maps. Powder Diffr. 1, 226-234.

Carr, M. J., Chambers, W. F., Melgaard, D., Himes, V. L., Stalick, J. \& Mighell, A. D. (1989). NIST/Sandial ICDD Electron Diffraction Database: a database for phase identification by electron diffraction. J. Res. Natl Inst. Stand. Technol. 94, 15-20.

Chung, F. H. (1974a). Quantitative interpretation of X-ray patterns of mixtures. I. Matrix-flushing method for quantitative multicomponent analysis. J. Appl. Cryst. 7, 519-525.

Chung, F. H. (1974b). Quantitative interpretation of X-ray patterns of mixtures. II. Adiabatic principle of $X$-ray diffraction analysis of mixtures. J. Appl. Cryst. 7, 526-531.

COHEN, M. U. (1936a). Elimination of systematic errors in powder photographs. Z. Kristallogr. 94, 288-298.

COHEN, M. U. (1936b). Calculation of precise lattice constants from X-ray powder photographs. Z. Kristallogr. 94, 306-310.

COOPER, M. J., Rouse, K. D. \& Sakata, M. (1981). An alternative to the Rietveld profile refinement method. $Z$. Kristallogr. 157, 101-117. 
Copeland, L. E. \& BragG, R. H. (1958). Quantitative $X$-ray diffraction analysis. Anal. Chem. 30, 196-201.

Crennell, K. M. \& Crisp, G. M. (1984). An enhanced interactive PLUTO78 for molecular display. J. Appl. Cryst. 17, 366-368.

Cullity, B. D. (1978). Elements of X-ray Diffraction, 2nd ed. Reading, MA: Addison-Wesley.

Caussin, P., Nusinovici, J. \& BEard, D. W. (1989). Specific data handling techniques and new enhancements in a searchimatch program. Adv. X-ray Anal. 32, $531-538$.

Dana, J. D. (1837). System of Mineralogy, 1st ed. New Haven, CN: Durrie and Peck and Herrick and Noyes.

Davis, B. L. (1986). Reference Intensity Method of Quantitative $X$-ray Diffraction Analysis. South Dakota School of Mines, Rapid City, SD, USA.

DinNebier, R. E. \& EYSEL, W. (1990). GUFI, an integrated program for evaluation of powder diffraction data. IUCr Symposium on Powder Diffraction, Toulouse, France. Abstracts, p. 279.

Dollase, W. A. (1986). Correction of intensities for preferred orientation in powder diffractometry: application of the March model. J. Appl. Cryst. 19, 267-272.

Donnay, J. D. H., Nowacki, W. \& Donnay, G. (1954). Crystal Data. Memoir 60, Geological Society of America, Boulder, CO, USA.

DowTy, E. (1988). Shape software for drawing crystals on personal computers. J. Appl. Cryst. 21, 211.

EDMONDS, J. W. (1980). Generalization of the Frevel ZRDSEARCH-MATCH program for powder diffraction analysis. J. Appl. Crist. 13, 191-192.

ELSENHANS, O. (1990). MINREF - a computer program for neutron refinement of incommensurate multiphase nuclear and magnetic structures. J. Appl. Cryst. 23, 73-76.

Enzo, S., Fagherazzi, G., Benedetti, A. \& Polizzi, S. (1988). A profile-fitting procedure for analysis of broadened $X$-ray diffraction peaks. I. Methodology. J. Appl. Cryst. 21, 536-542.

Espinat, D. \& Thevenot, F. (1990). Structural description of the amorphous and poorly-crystalline solids by $X$-ray powder diffraction: application of a new powerful software for pattern simulation. IUCr Symposium on Powder Diffraction, Toulouse, France. Abstracts, p.79.

Fiala, J. (1985). Spectral databases for chemical compound identification. Comput. Phys. Commun. 33, 85-92.

Fiala, J. \& Fialova, J. (1985). Computerized $X$-ray powder diffraction identification system. Chem. Listy, 79, 4857.

FISCHER, R. X. (1985). STRUPLO84, a Fortran plot program for crystal structure illustrations in polyhedral representation. J. Appl. Cryst. 18, 258-262.

Fleischer, M. (1987). Glossary of Mineral Species. Tuscon, AZ: Mineralogical Record.

Frevel, L. K. (1982). Structure-sensitive search-match procedures for powder diffraction analysis. Anal. Chem. 54, 691-697.

Frevel, L. K., Adams, C. E. \& Ruhberg, L. R. (1976). A fast search-match program for powder diffraction analysis. J. Appl. Cryst. 9, 199-204.

Gabe, E. J., LePage, Y., Charland, J.-P., Lee, F. L. \& WhITE, P. S. (1989). NRCVAX - an interactive program system for structure analysis. J. Appl. Cryst. 22, 384 387.
GaRveY, R. G. (1986a). UNITCELL finds unit cell parameters from a powder diffraction pattern. Powder Diffr. 1 , 89.

GarveY, R. G. (1986b). LSUCRIPC least squares unit cell refinement with indexing on the personal computer. Powder Diffr. 1, 114.

Gerward, L. \& OLSEN, J. S. (1987). EDDA-program for predicting energy-dispersive powder diffraction spectra. $J$. Appl. Cryst. 20, 324.

Golbel, J. B. \& Wilson, A. S. (1965). Indexing Program for Indexing $X$-ray Diffraction Pouder Patterns. Report BNWL-22. Batelle Northwest Laboratories, Batelle, USA.

GOEHNER, R. P. (1979). SPECPLOT - an interactive data reduction and display program for spectral data. Adv. $X$-ray Anal. 23, 305-311.

Goehner, R. P. \& Garbauskas, M. F. (1983a). Computeraided qualitative $X$-ray pouder diffraction phase analysis. Adv. X-ray Anal. 26, 81-86.

Goehner, R. P. \& Garbaliskas, M. F. (1983b). PDIDENT - a Sel of Complete Programs for Powder Diffraction Phase Identification. General Electric Technical Information Series 83CRD062, Schenectady, NY, USA.

Hatfiner, C., Elf, F. \& Will, G. (1990). An interactive PC program for profile analysis of severely overlapping peaks. IUCr Symposium on Powder Diffraction, Toulouse, France. Abstracts, p. 81 .

Hanawalt, J. D., Rinn, H. W. \& Frevel, L. K. (1938). Chemical analysis by $X$-ray diffraction - classification and use of $X$-ray diffraction patterns. Ind. Eng. Chem. Anal. Ed. 10, 457-512.

Hill, R. J., Foxworthy, A. M. \& White, R. J. (1990). PEAKS: a PC-based method for quantitative $X$-ray diffraction phase analysis of lead-acid battery materials. $J$. Power Sources, 32, 315-328.

Hill, R. J. \& Madsen, I. C. (1984). Structural parameters of $\beta$-lead dioxide and their relation to the hydrogen-loss concept of lead-acid battery failure. J. Electrochem. Soc. 131, 474-482, $1486-1491$.

Himes, V. L. \& Mighell, A. D. (1985). NBS* LATTICE: $a$ Program to Analyze Lattice Relationships. NIST Crystal Data Center, Gaithersburg, MD, USA.

Himes, V. L. \& MighelL, A. D. (1987). NSB Crystal Data: $N B S^{*} S E A R C H$ : a program to search the database. In Crystallographic Databases, edited by F. H. Allen, G. BergerhofF \& R. Sievers, pp. 144-155. International Union of Crystallography, Chester, England.

HOVESTREYDT, E. R. (1983). FINAX: a computer program for correcting diffracting angles, refinining cell parameters and calculating powder patterns. J. Appl. Cryst. 16, 651-653.

Hovestreydt, E. R., Parthé, E. \& Benedict, U. (1988). ENDIX: a program to simulate energy dispersive $X$-ray powder diffraction diagrams. J. Appl. Cryst. 21, 282-283.

HowARD, S. A. \& SNYDER, R. L. (1983). Evaluation of some profile models used in profile fitting. Adv. X-ray Anal. 26, 73-80.

Hubbard, C. R. (1980). Standard reference materials for quantitative analysis and $d$-spacing measurements. In Accuracy in Powder Diffraction, edited by S. BLock \& C. R. Hubbard. Natl Bur. Stand. Spec. Publ. No. 567, pp. 489-502. 
Hubbard, C. R. (1983a). New standard reference materials for X-ray powder diffraction. Adv. X-ray Anal. 26, 45-51.

Hubbard, C. R. (1983b). Certification of $\mathrm{Si}$ powder diffraction Standard Reference Material 640a. J. Appl. Cryst. 16, 285-288.

Hubbard, C. R., Evans, E. H. \& Smith, D. K. (1976). The reference intensity ratio, $I / I_{c}$, for computer simulated powder patterns. J. Appl. Cryst. 9, 169-174.

Iтo, T. (1950). X-ray Siudies on Polymorphism. Tokyo: Maruzen.

International Tables for X-ray Crystallography (1959). Vol. II. Birmingham: Kynoch Press. (Present distributor Kluwer Academic Publishers, Dordrecht.)

International Tables for X-ray Crysallography (1965). Vol. I. Birmingham: Kynoch Press.

IzUMI, F. (1985). A computer program for Rietveld analysis of $X$-ray and neutron diffraction patterns. Kobutsugaka Zasshi, 17, 37-50.

IzUml, F. (1985). A software package for Rietveld analysis of $X$-ray and neutron diffraction patterns. Nippon Kessho Gakkaishi 27, 23-31.

Izumi, F., Asano, H., Murata, H. \& Watanabe, N. (1987). Rietveld analysis of powder patterns obtained by TOF neutron diffraction using cold neutron sources. $J$. Appl. Cryst. 20, $411-418$.

Jenkins, R. \& Smith, D. K. (1987). Powder Diffraction File. In Crystallographic Databases, edited by F. H. Allen, G. Bergerhoff \& R. Sievers, pp. 158-177. International Union of Crystallography, Chester, England.

JOHNSON, C. K. (1970). ORTEP: a Fortran ThermalEllipsoid Program for Crystal Structure Illustrations. Report ORNL-3794. (ORTEPII, Report ORNL-5138). Oak Ridge National Laboratory, Oak Ridge, TN, USA.

Johnson, G. G. JR \& VAND, V. (1967). A compulerized powder diffraction identification system. Ind. Eng. Chem. 59, 19-26.

JoHnson, Q. (1985). X-ray diffraction search match for a micro-computer. Proc. 36th Pittsburgh Conference and Exposition, New Orleans, LA, USA.

KELLER, E. (1989). Some computer drawings of molecular and solid-state structures. J. Appl. Cryst. 22, 19-22.

KluG, H. P. \& AleXander, L. E. (1974). X-ray diffraction procedures for polycrystalline and amorphous materials, 2nd ed. New York: Wiley.

Kogan, V. A. (1988). PhD thesis. Rostov-on-Don Univ., USSR.

KOHLBECK, F. \& HÖERL, E. M. (1976). Indexing program for powder patterns especially suitable for triclinic, monoclinic and orthorhombic lattices. J. Appl. Cryst. 9, 2833.

KOHLBECK, F. \& HöERL, E. M. (1978). Trial and error indexing program for powder patterns of monoclinic substances. J. Appl. Cryst. 11, 60-61.

Ladell, J., Zagofsky, A. \& Pearlman, S. (1975). Cu $K \alpha_{2}$ elimination algorithm. J. Appl. Cryst. 8, 499-506.

Langford, J. I. (1971). Powder pattern programs. J. Appl. Cryst. 4, 259-260.

Langford, J. I., Louër, D., Sonneveld, E. \& VisSer, J. W. (1986). Applications of total pattern fitting to a study of crystallite size and strain in zinc oxide powder. Powder Diffr. 1, 211-221.
Larson, A. C. \& Von Dreele, R. B. (1987). GSAS, Generalized Crystal Structure Analysis System. Report LAUR-86-748. Los Alamos National Laboratory, Los Alamos, NM, USA.

LAugier, J. \& Filhol, A. (1983). An interactive program for the interpretation and simulation of Laue patterns. $J$. Appl. Cryst. 16, 281-283.

LAWTON, S. L. (1967). TRACERII, a Fortran Latice Transformation-Cell Reduction Program (an extended version of TRACER I). Mobil Research \& Development Corporation, Research Department, Palusboro, NJ, USA.

LE BAIL, A. \& LoUËR, D. (1978). Smoothing and validity of crystallite-size distributions from $X$-ray line-profile analysis. J. Appl. Cryst. 11, 50-55.

Lebrun, J. L., Spravel, J. M. \& Maeder, G. (1981). Use of a position-sensitive detector. Adv. X-ray Anal. 32, 531-538.

LENGAUER, C. L. (1990). Hard-and software "tools" for high precision powder diffraction data in routine $X$-ray analysis. IUCr Symposium on Powder Diffraction, Toulouse, France. Abstracts, p. 35.

Lin, T.-H., Zhang, S.-Z., Chen, L.-J. \& CaI, X.-X. (1983). An improved program for searching and matching of $X$-ray ponder diffraction patterns. J. Appl. Cryst. 16, $150-154$.

LOUËr, D. \& LOUËR, M. (1972). Méthode d'essais et erreurs pour l'indexation automatique des diagrammes de poudre. J. Appl. Cryst. 5, 271-275.

LOUËR, D. \& VARGAS, R. (1982). Indexation automatique des diagrammes de poudre par dichotomies successives. $J$. Appl. Cryst. 15, 542-545.

LoUër, D., VARGas, R. \& AuprRedic, J. P. (1984). Morphological analysis and growth of crystallites during annealing of $\mathrm{ZnO} . J . A m$. Ceram. Soc. 67, 163140.

Louër, D., Weigel, D. \& Louboutin, R. (1969). Méthode directe de correction des profils de raies de diffraction de rayons $X$. I. Méthode numérique de déconvolution. Acta Cryst. A25, 335-338.

Luo, J., Ammon, H. L. \& Gilliland, G. L. (1989). PLOTMD - an interactive program to modify molecular plots on a graphics terminal. J. Appl. Cryst. 22, 186.

MCCARTHY, G. J. (1986). LOTUS 1-2-3 templates for XRD and $X R F$. Powder Diffr. 1[2], 89.

MCDOnald, R. S. \& Wilks, P. A. JR (1988). JCAMP-DX: a standard form for exchange of infrared spectra in computer-readable form. Appl. Spectrosc'. 42, 151162.

MADSEN, I. C. \& Hill, R. J. (1990). QPDA - a userfriendly, interactive program for quantitative phase and crystal size/strain analysis of powder diffraction data. Powder Diffr. 5, 195-199.

Mallory, C. L. \& Snyder, R. L. (1979). The Alfred University Powder Diffraction System. Technical Paper no. 144, New York State College of Ceramics, Alfred Univ., Alfred, NY, USA.

MARQUART, R. G. (1986). $\mu$ PDSM: mainframe search' match on an IBM PC. Powder Diffr. 1, 34-39.

Marquart, R. G., Katsnelson, I., Milne, G. W. A., Heller, S. R., Johnson, G. G. JR \& Jenkins, R. (1979). A search-match system for $X$-ray powder diffraction dala. J. Appl. Cryst. 12, 629-634. 
Masden, J. C., Skov, H. J. \& Rasmussen, S. E. (1988). An inexpensive automation of a pou'der diffractometer. Powder Diffi. 3, 91-92.

Merz, P., Jansen, E., SChäfer, W. \& Will, G. (1990a). PROFAN/PC: a program for powder peak profile analysis. J. Appl. Cryst. 23, 444-445.

Merz, P., Jansen, E., Schafer, W. \& Will, G. (1990 $b$ ). $A$ $P C$-program for powder peak profile analysis. IUCr Symposium on Powder Diffraction. Toulouse, France. Abstracts, p. 83.

Mighell, A. D., Hlibard, C. R., Stalick, J. K. \& Holomany. M. A. (1983). NBS*AIDS83: a Manual Describing the Data Format Used in NBS*AIDS83. JCPDS-International Centre for Diffraction Data, Swarthmore, PA, USA.

Mighell. A. D.. Stalick, J. K. \& Himes, V. L. (1987). NBS Cristal Data: Datahase description and applications. In Cristallographic Databases, edited by F. H. Allen, G. Bergerhoff \& R. Sievers, pp. 134-143. International Union of Crystallography, Chester, England.

Mueller, M. H. \& HeatoN, L. (1961). Determination of Lattice Parameters with the Aid of a Computer. Report ANL-6176. Argonne National Laboratory, Argonne, IL. USA.

Mugnoli. A. (1985). A micro-computer program to detect higher lattice simmetry. J. Appl. Crist. 18, 183-184.

Niggli, P., Ewald, P. P., Fajans, K. \& von Laue, M. (1931). Structurberich-Ergoenzungsband der Zeitschrift für Kristallographie, Vol. 1. Leipzig: Akademische Verlagsgeseuschaft $\mathrm{mBH}$.

Novak, G. A. \& Colville, A. A. (1989). A practical interactive least-squares cell-parameter program using an electronic spreadsheet and a personal computer. Am. Mineral. 74, 488-490.

Nusinovici, J. \& ReHFELdT-OSKIERSKi, A. (1990). DIFFRACT-AT search/match and profile fitting programs. IUCr Symposium on Powder Diffraction, Toulouse, France. Abstracts, p. 315.

O'Connor, B. H. \& Bagliani, F. (1976). A semiautomated system for identifying crystalline materials with ponder diffraction data. J. Appl. Crist. 9, 419423 .

O'Connor. B. H. \& Chang, W.-J. (1984). A procedure for searchimatch anulysis of $X$-ray powder diffraction palterns using compact data bases. J. Appl. Cryst. 17. $212-214$

PASkOWICZ, W. (1989). INDEXING-program for indexing pouder patterns of cubic, tetragonal, hexagonal and orthorhombic substances on personal computers. J. Appl. Crvist. 22, 186-187.

PAWLEY, G. S. (1980). EDINP, the Edinburgh powder profile refinement program. J. Appl. Crist. 13, 630633.

Pawley, G. S. (1981). Unit-cell refinement from powder diffraction scans. J. Appl. Cryst. 14, 357-361.

Petkov, V. \& Bakaltchev, N. (1990). FIT, a computer program for decomposition of powder diffraction patterns and profile analysis of pair correlation functions. J. Appl. Cryst. 23, 138-140.

Pyrros, N. P. \& Hubrard, C. R. (1983). POWDER PATTERN: a system of programs for processing and interpreting powder diffraction data. Adv. X-ray Anal. 26, $63-72$.
RACHINGER. W. A. (1948). A correction of the $\alpha_{1} \alpha_{2}$ doublet in the measurement of the widths of $X$-ray diffraction lines. J. Sci. Instrum. 25, 254-255.

RADHAKRISHNAN, R. (1982). A molecular plotting program. J. Appl. Cryst. 15, 135-136.

Rietveld, H. M. (1967). Line profiles of neutron powderdiffraction peaks for structure refinement. Acta Cryst. 22 , 151-152.

RiETVELD, H. M. (1969). A profile refinement method for nuclear and magnetic structures. J. Appl. Crist. 2, 65-71.

Rodgers, J. D. \& WoOd, G. H. (1987). NRCC Metals Crystallographic Data File (CRYSTMET). In Crystallographic Databases, edited by F. H. Allen, G. BerGerHOFF, \& R. SIEVERS, pp. 96-106. International Union of Crystallography, Chester, England.

ROGERS, K. D. (1990). TEXCAM - an interpretation aid for cylindrical texture camera $X$-rav diffraction patterns. J. Appl. Cryst. 23, 347--348.

Rogers, K. D. \& LANE, D. W. (1987). A simple system for enhanced data collection from a pouder diffractometer. Powder Diffr. 2, $227-229$.

RoOF, R. B. \& Elliot, R. O. (1975). Evidence for the existence of faulting in a splat-cooled $\delta$-plutonium-rich titanium alloy. J. Mater. Sci. 10, 101-108.

Rouse, K. D., CoOper, M. J. \& SAKata, M. (1981). SCRAP, a Program for the Analysis of Powder Diffraction Patterns. Report AERE-R9718. AERE, Harwell, England.

Sakurai. T., Kobayashi, K.. Horiki, T., Furukawa, M. \& NaITOU. K. (1989). CRYST - a system to display $3 D$ images of crystal structure, symmetry operations and cristal forms. J. Appl. Crist. 22, 633-639.

Savitsky, A. \& Golay. M. J. E. (1964). Smoothing and differentiation of data by simplified least squares procedures. Anal. Chem. 36, 1627-1639. Correction: Steiner, J., Termonia, Y. \& Deltour, J. (1974). Comments on smoothing and differentiation of data by simplified least squares procedures. Anal. Chem. 44, 1906 1909.

SChneider, J., Rejth, W., Klehe, A.-K. \& Ehilling, J. S. (1990). Application of $P C$-Rietveld refinement: variation of $T_{6}$ with bond length in tetragonal $\mathrm{Tl}_{2} \mathrm{Ba}_{2} \mathrm{CuO}_{6}$. IUCr Symposium on Powder Diffraction, Toulouse, France. Abstracts, p. 159.

Scotr, H. G. (1990). Refinement of the crystal structure of the manganous antimonate $\mathrm{Mn}_{2} \mathrm{Sb}_{2} \mathrm{O}_{7}$ with neutron diffraction data by the profile decomposition method. $Z$. Kristallogr. 190, 41-46.

Setten, A. \& SeTten, R. (1979). AIDED, a program for the automatic indexing of epitaxic derivatives; application to the graphite lamellar compounds. J. Appl. Cryst. 12, 147-150.

SHIRlEY, R. (1980). Data accuracy for powder indexing. In Accuracy in Powder Diffraction. edited by S. BLock \& C. R. Hubbard. Nall Bur. Stand. Spec. Publ. No. 567.

SHIRlEY, R. \& LOUËR, D. (1978). New powder indexing programs for any symmetry which combine grid-search with successive dichotomy. Acta Cryst. A34, S382.

Sмгтн, D. K. (1989). Computer analysis of diffraction data. In Modern Powder Diffraction. MSA Short Course Notes 20, edited by D. L. BISH \& J. E. Post. Washington, DC: Mineralogical Society of America. 
Smith, D. K., Johnson, G. G. JR, Kelton, M. J. \& ANDERSON, C. A. (1989). Chemical constraints in quantitative $X$-ray powder diffraction for mineral analysis of the sand/silt fraction of sedimentary rocks. Adv. X-ray Anal. 32, 488-496.

Smith, D. K., Johnson, G. G. JR, Schieble, A., Wims, A. M., Johnson, J. L. \& UllmanN, G. (1987). Quantitative $X$-ray powder diffraction method using the full diffraction pattern. Powder Diffr. 2, 73-77.

Smith, D. K., Nichols, M. C. \& Zolensky, M. E. (1983). POWD10, a Fortran IV program for calculating $X$-ray powder diffraction patterns. The Pennsylvania State Univ., University Park, PA, USA.

Smith, G. S. \& Kahara, E. (1975). Automated computer indexing of powder patterns: the monoclinic case. J. Appl. Cryst. 8, 681-683.

SMITH, G. S. \& SNyder, R. L. (1979). $F_{N}:$ a criterion for rating powder diffraction patterns and evaluating the reliability of powder-pattern indexing. J. Appl. Cryst. 12, $60-65$.

Snyder, R. L., Hubbard, C. R. \& Panagiotopollos (PYrRos), N. P. (1982). A second generation automated powder diffraction control system. Adv. X-ray Anal. 25, $245-260$.

Sonneveld, E. J. \& Visser, J. W. (1975). Automatic collection of powder data from photographs. J. Appl. Cryst. 8 , $1-7$.

SPEK, A. L. (1988). LEPAGE - an MS-DOS program for the determination of the metrical symmetry of a translation lattice. J. Appl. Cryst. 21, 578-579.

Stalick, J. K. \& Mighell, A. D. (1986). Crystal Data, Version 1.0, Database Specifications. Natl Bur. Stand. Tech. Note No. 1229.

STEENSTRUP, S. (1981). A simple procedure for fitting a background to a certain class of measured spectra. J. Appl. Cryst. 14, 226-229.

Stewart, J. M. \& Hall, S. R. (1985). XTAL, a program system for crystallographic calculations. J. Appl. Cryst. 18, 263.

TAUPIN, D. (1968). Une méthode générale pour l'indexation des diagrammes de poudres. J. Appl. Cryst. 1, 178-181.

TAUPIN, D (1989). Enhancements in powder-pattern indexing. J. Appl. Cryst. 22, 455-459.

TAYLOR, J. C. (1991). Computer programs for standardless quantitative phase analysis of minerals using the full powder diffraction profile. Powder Diffr. 5, 2-9.

Toby, B. H., Harlow, R. L. \& Holomany, M. A. (1989). The POWDER SUITE: computer programs for searching and accessing the JCPDS-ICDD powder diffraction database. Powder Diffr. 5, 2-7.

TORAYA, H. (1986). Whole-powder-pattern fitting without reference to a structural model: application to $X$-ray powder diffraction. J. Appl. Cryst. 19, 440-447.

Toraya, H., Yoshimura, M. \& Sōmiya, A. (1983). A computer program for the deconvolution of $X$-ray diffraction profiles with the composite of Pearson type VII functions. J. Appl. Cryst. 16, 653-657.

TRAN, V. \& BULÉON, A. (1987). Diffraction peak shapes: a profile refinement method for badly resolved powder diagrams. J. Appl. Cryst. 20, $430-436$.

Ugliengo, P., Borzani, G. \& Viterbo, D. (1988). MOL$D R A W$ - program for the graphical manipulation of molecules on personal computers. J. Appl. Cryst. 21, 75.
VILA, E. \& RuIZ-Amil, A. (1988). Computer program for analysing interstratified structures by Fourier transform methods. Powder Diffr. 3, 7-11.

VISSER, J. W. (1969). A fully automatic program for finding the unit cell from powder data. J. Appl. Cryst. 2, 89-95.

WANG, S. L., WANG, P. C. \& NiEH, Y. P. (1990). Structure determination of $\mathrm{LiMnP}_{2} \mathrm{O}_{7}$ from multiphase powder $X$-ray diffraction data. J. Appl. Cryst. 23, 520-525.

Warren, B. E. \& Averbach, B. L. (1950). The effect of cold-work distortion on X-ray patterns. J. Appl. Phys. 21, 595-598.

WERNER, P.-E. (1964). Trial and error computer methods for the indexing of unknown powder patterns. Z. Kristallogr. 120, 375-387.

WERNER, P.-E. (1969). Fortran programs for least-squares refinemement of crystal structure cell dimensions. Ark. Kemi, 31, 513-516.

WERNER, P.-E. (1969). Integrated s't of programs for the calculations of structure factors from an automatic filmscanner process. Ark. Kemi, 31, 505-511.

Werner, P.-E., ERIKSSON, L. \& Westdahl, M. (1985). TREOR, a semi-exhaustive trial-and-error powder indexing program for all symmetries. J. Appl. Cryst. 18, 367-370.

Wiedemann, K. E., Unnam, J. \& Clark, R. K. (1987). Computer program for deconvoluting powder diffraction spectra. Powder Diffr. 2, 137-145.

Wiles, D. B. \& Young, R. A. (1981). A new computer program for Rietveld analysis of $X$-ray powder diffraction patterns. J. Appl. Cryst. 14, 149-151.

WILL, G. (1979). POWLS: a powder least-squares program. J. Appl. Cryst. 12, 483-485.

Will, G., JANSEN, E. \& Shafer, W. (1989). 12th European Crystallogr. Meet., Moscow, USSR, pp. 20-29.

WILson, A. J. C. (1963). Mathematical Theory of $X$-ray Powder Diffractometry. Philips Technical Library, Eindhoven, The Netherlands.

Wims, A. M., Myers, M. E. JR, Johnson, J. L. \& Carter, J. M. (1986). Computer capability for the determination of polymer crystallinity by $X$-ray diffraction. Adv. X-ray Anal. 29, 281-288.

WOLFF, P. M. DE (1957). On the determination of unit-cell dimensions from powder patterns. Acta Cryst. 10. 590-595.

WolfF, P. M. DE (1962). Indexing of powder diffraction patterns. Adv. X-ray Anal. 6, 1-17.

WOLFF, P. M. DE (1968). A simplified criterion for the reliability of a powder pattern indexing. J. Appl. Cryst. 1, 108-113.

WOLFF, P. M. DE (1972). The definition of the indexing figure of merit $M_{20}$.J. Appl. Cryst. 5, 243.

WOLFF, P. M. DE \& VISSER, J. W. (1964). Absolute intensities - outline of a recommended practice. TPD Technical Report No. 641-109. Reprinted (1988). Powder Diffr. 3, 202-204.

Wu, E. (1989). POWD, an interactive program for powder diffraction data interpretation and indexing. J. Appl. Cryst. 22, 506-510.

YoUNG, R. A. (1980). Structural analyses from $X$-ray powder diffraction patterns with the Rietveld method. In Accuracy in Powder Diffraction, edited by S. Block \& C. R. Hubbard. Natl Bur. Stand. Spec. Publ. No. 567, pp. 143-163. 
Young, R. A., Mackie, P. E. \& Von Dreele, R. B. Yvon, K., Jeitschko, W. \& Parthé, E. (1977). LAZY (1977). Application of the pattern-fitting siructure- PULVERIX, a computer program, for calculating X-ray refinement method to $X$-ray powder diffractometer pat- and neutron diffraction powder patterns. J. Appl. Cryst. terns. J. Appl. Cryst. 10, 262-269. 10, 73-74. 


\section{Powder Diffraction Program Information Centre Program Questionnaire}

\section{PLEASE PRINT ALL ANSWERS}

1. Program name:

2. Program function:

3. Author(s):

4. Address for primary author (including Email address):

5. Program language (machine, operating system, compiler vendor and version):

6. Will source code be supplied $(\mathrm{Y} / \mathrm{N})$ :

7. Would current and updated code be supplied to a central distribution site if one were to be established (Y/N):

8. Computers on which the program has been used successfully (indicate hardware requirements, memory size, math coprocessor (if any), graphics software and hardware, etc.):

9. Appropriate keywords (database, indexing, data reduction, identification, cell matching, intensity calculations, profile matching, profile deconvolution, crystallinity, structure refinement, structure solution, stress analysis, display, other):

10. Full literature references to program and its uses (if any):

11. Instructions for obtaining a copy of the program including any costs involved and the type of medium for the copy:

12. Sources for versions of the program which have been modified to run on computers other than the author's:

13. Documentation - machine readable or hard-copy:

14. Support will be provided by the author $(\mathrm{Y} / \mathrm{N})$ :

15. Program abstract:

Additional comments (note item number):

Mail to:

Deane K. Smith

Department of Geosciences

239 Deike Building

The Pennsylvania State University

University Park, PA 16802

USA

Email: DKS1@PSUVM or:

Syb Gorter

Gorlaeus Laboratories

State University of Leiden

Einsteinweg 5

NL-2333 CC Leiden

The Netherlands

Email: ASKASG@HLERUL2 